\title{
Argonne
}

ANL-20/01

\section{Surveillance of Site A and Plot M}

Report for 2019

Environment, Safety, Health, and Quality Directorate

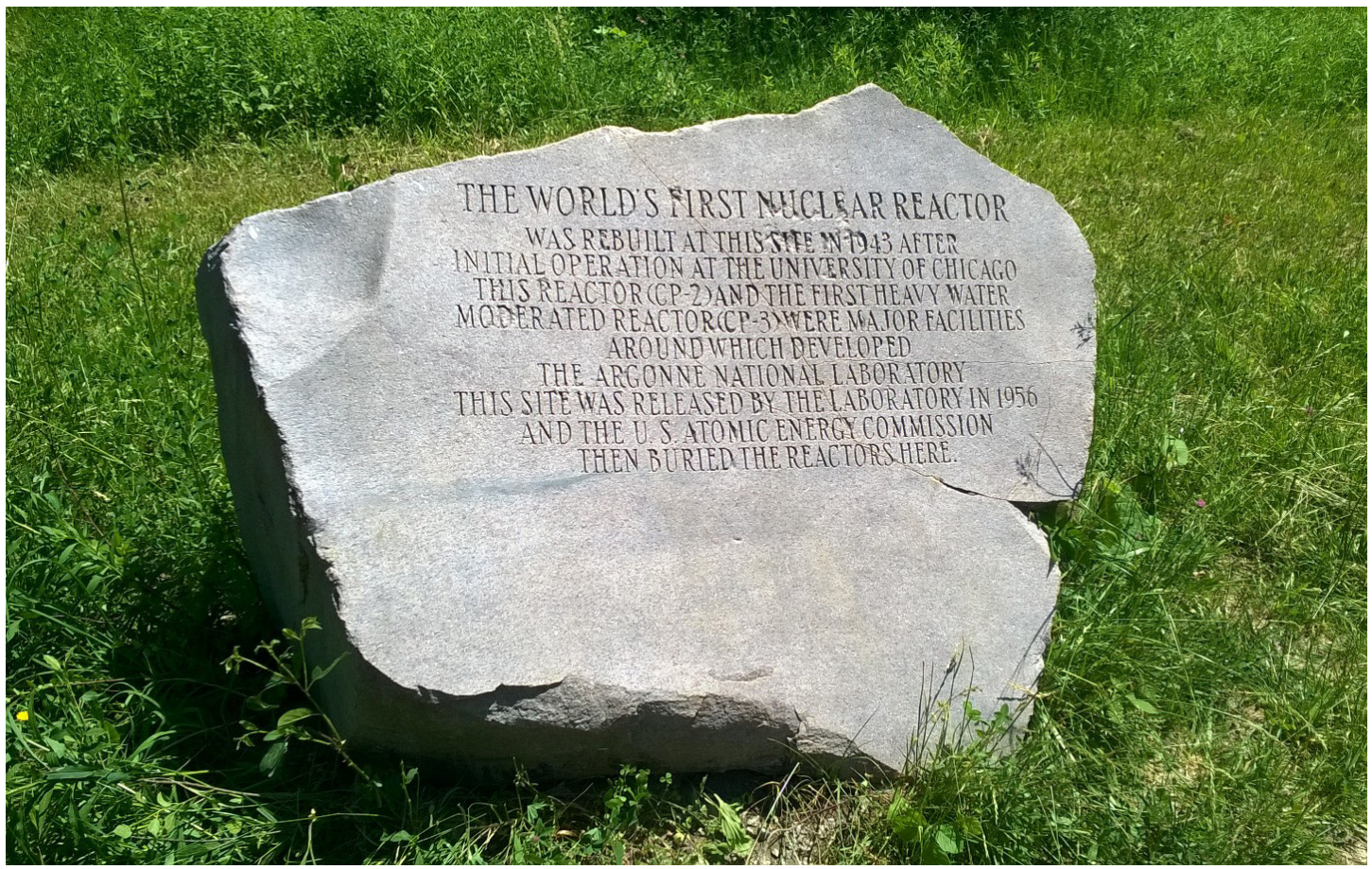




\begin{abstract}
About Argonne National Laboratory
Argonne is a U.S. Department of Energy laboratory managed by UChicago Argonne, LLC under contract DE-AC02-06CH11357. The Laboratory's main facility is outside Chicago, at 9700 South Cass Avenue, Argonne, Illinois 60439. For information about Argonne and its pioneering science and technology programs, see www.anl.gov.
\end{abstract}

\title{
DOCUMENT AVAILABILITY
}

Online Access: U.S. Department of Energy (DOE) reports produced after 1991 and a growing number of pre-1991 documents are available free at OSTI.GOV (http://www.osti.gov/), a service of the U.S. Dept. of Energy's Office of Scientific and Technical Information

Reports not in digital format may be purchased by the public from the National Technical Information Service (NTIS):

U.S. Department of Commerce

National Technical Information Service

5301 Shawnee Rd

Alexandria, VA 22312

www.ntis.gov

Phone: (800) 553-NTIS (6847) or (703)

605-6000 Fax: (703) 605-6900

Email: orders@ntis.gov

Reports not in digital format are available to DOE and DOE contractors from the Office of Scientific and Technical Information (OSTI):

U.S. Department of Energy

Office of Scientific and Technical Information

P.O. Box 62

Oak Ridge, TN 37831-0062

www.osti.gov

Phone: (865) 576-8401

Fax: (865) 576-5728

Email: reports@osti.gov

\section{Disclaimer}

This report was prepared as an account of work sponsored by an agency of the United States Government. Neither the United States Government nor any agency thereof, nor UChicago Argonne, LLC, nor any of their employees or officers, makes any warranty, expressor implied, or assumes any legal liability or responsibility for the accuracy, completeness, or usefulness of any information, apparatus, product, or process disclosed, or represents that its use would not infringe privately owned rights. Reference herein to any specific commercial product, process, or service by trade name, trademark, manufacturer, or otherwise, does not necessarily constitute or imply its endorsement, recommendation, or favoring by the United States Government or any agency thereof. The views and opinions of document authors expressed herein do not necessarily state or reflect those of the United States Government or any agency thereof. 
ANL-20/01

\section{Surveillance of Site A and Plot M}

Report for 2019

prepared by

Robert E. Piorkowski

Environment, Safety, Health, and Quality Directorate, Argonne National Laboratory

August 2020 
This page intentionally left blank 


\section{PREFACE}

This report is prepared for the U. S. Department of Energy (DOE) by the Quality Assurance and Service Division (QAS) at Argonne National Laboratory (Argonne). The results of the environmental monitoring program at Site $\mathrm{A}$ and Plot $\mathrm{M}$ and an assessment of the impact of the site on the environment and the public are presented in this publication. Funding to support this program was provided by the DOE Office of Legacy Management (LM).

Sample collection, field measurements, and data management were conducted under the direction of Gerald Baudino, QAS Environmental Monitoring Group:
Jenny Gomez
Rob Piorkowski
Steven Miller
Jenni Tucker

The analytical separations and measurements were conducted under the direction of Anil Thakkar, QAS Analytical Services Interim Manager by:
John Dyer
Jessica Frigon
Matt Nagrodski
Mary Salisbury
Anil Thakkar

This manuscript was prepared for publication by Terri Schneider (QAS). 
This page intentionally left blank 


\section{TABLE OF CONTENTS}

Page

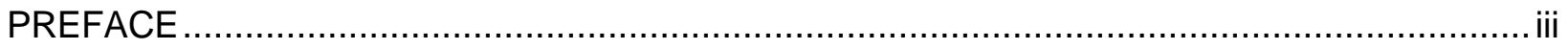

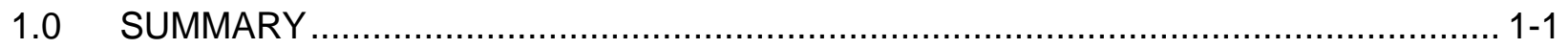

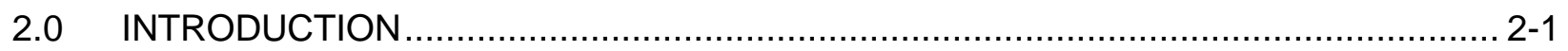

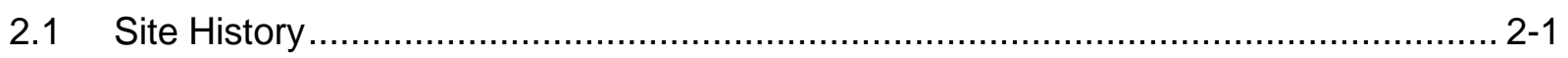

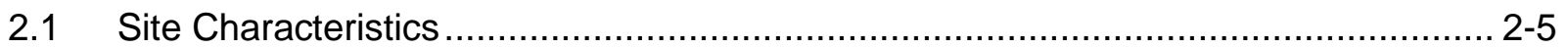

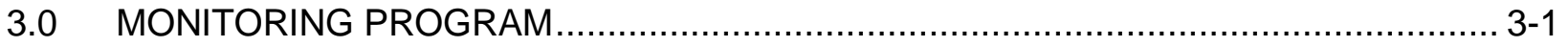

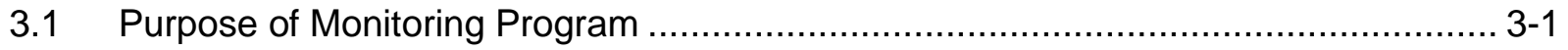

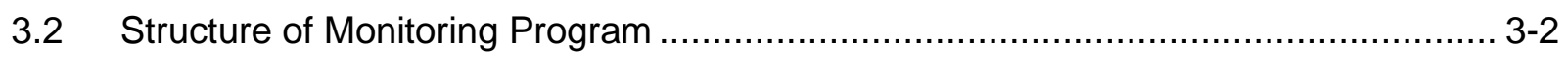

4.0 RESULTS OF THE MONITORING PROGRAM ............................................... 4

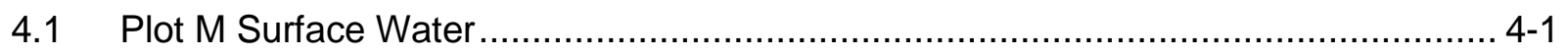

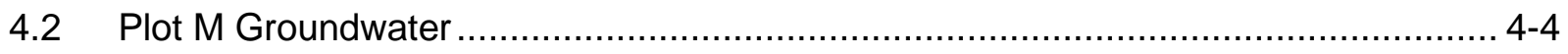

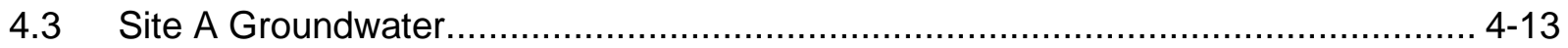

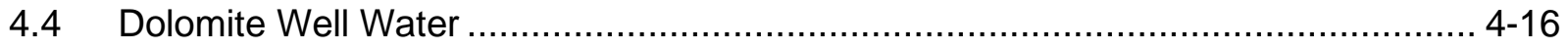

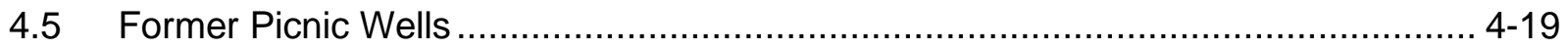

5.0 SUMMARY OF POTENTIAL RADIATION DOSE AND RISK ESTIMATES.................. 5-1

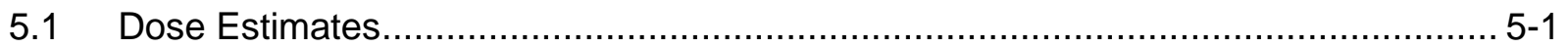

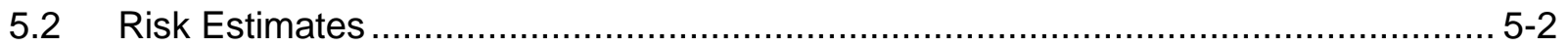

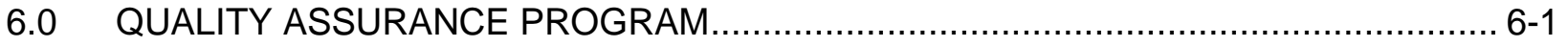

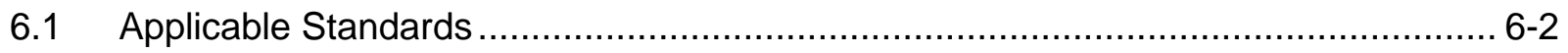

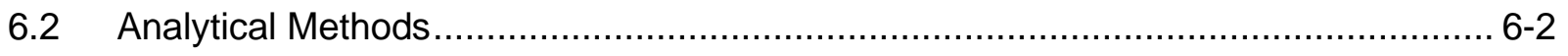

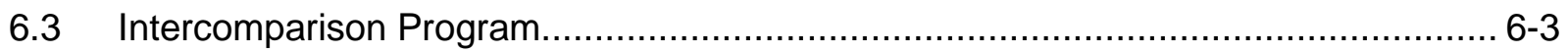

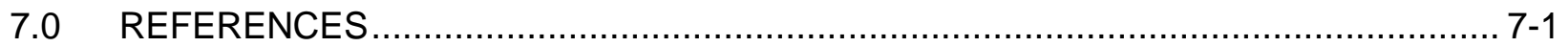

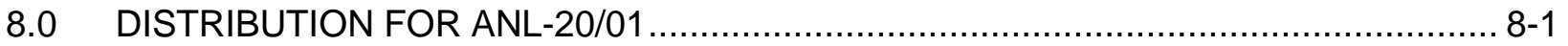

9.0 APPENDIX A- 2019 IEMA ANALYTICAL DATA FOR SITE A /PLOT M...................... 9-1 


\section{LIST OF TABLES}

No.

$\underline{\text { Title }}$

Page

Table 3.1 Environmental Monitoring Program for Site A and Plot M ............................... 3-3

Table 4.1 Hydrogen-3 Content of Stream Next to Plot M, 2019 .................................... 4-7

Table 4.2 Hydrogen-3 Content of Site A Area Ponds, 2019 ........................................ 4-4

Table 4.3 Hydrogen-3 Content of Plot M Monitoring Well Water, 2019............................. 4-6

Table 4.4 Strontium-90 Content of Monitoring Well Water Samples Near Plot M, 2019........ 4-11

Table 4.5 Water Level Measurements in Monitoring Wells Near Plot M, 2019 ................... 4-12

Table 4.6 Hydrogen-3 Content of Monitoring Well Water Samples Near Site A, 2019 ......... 4-13

Table 4.7 Strontium-90 Content of Monitoring Well Water Samples Near Site A, 2019 ........ 4-13

Table 4.8 Water Level Measurements in Monitoring Wells Near Site A, 2019 .................. 4-15

Table 4.9 Hydrogen-3 Content of Dolomite Well Water, 2019 ...................................... 4-18

Table 4.10 Water Level Measurements in Dolomite Wells, 2019................................ 4-20

Table 4.11 Hydrogen-3 Content of Former Picnic Wells Near Site A/Plot M, 2019 ............. 4-20

Table 4.12 Hydrogen-3 Concentrations in the Red Gate Woods Wells .......................... 4-21

Table 5.1 Hypothetical Dose from Exposure to Hydrogen-3, 2019 .................................. 5-3

Table 5.2 Hypothetical Dose Hydrogen-3 Exposures to a Casual Visitor, 2019................... 5-3

Table 5.3 Annual Average Dose Equivalent in the U. S. Population .................................. 5-4

Table 5.4 Annual Risk of Death from Various Events .................................................... 5-5

Table 6.1 Intercomparison Sample Hydrogen-3 Results for 2019................................... 6-4

Table 6.2 Intercomparison Sample Strontium-90 Results for 2019............................... 6-5

Table 6.3 Intercomparison Sample Cesium-137 Results for 2019 ................................ 6-6 


\section{LIST OF FIGURES}

Figure 1.1 View of timber steps installed along northeast path at Plot M ............................ 1-3

Figure 1.2 Northeast view of timber steps installed along the path at Plot M ...................... 1-4

Figure 1.3 North view of timber steps installed along northeast path at Plot M ....................1-5

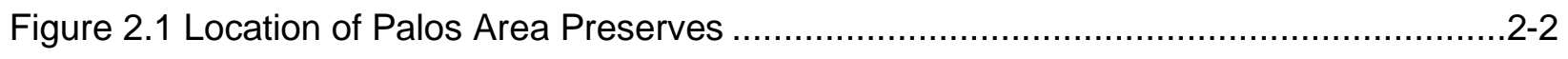

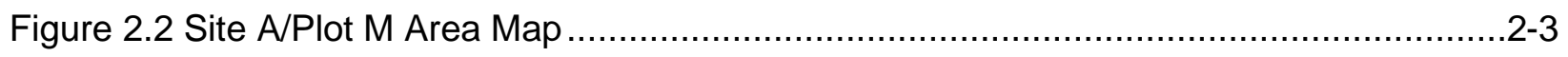

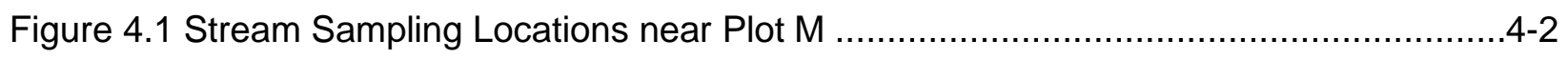

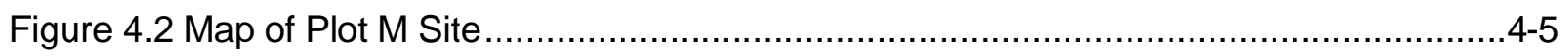

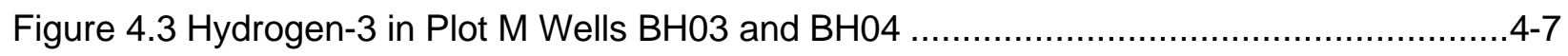

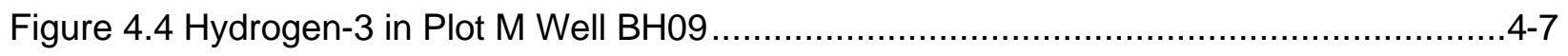

Figure 4.5 Hydrogen-3 and Groundwater Elevation in Well BH06 ................................9

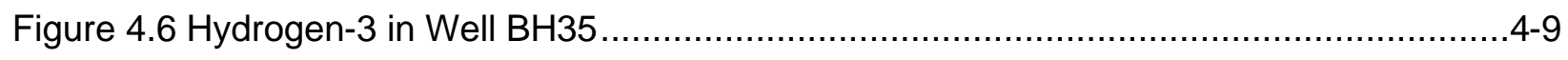

Figure 4.7 Hydrogen-3 and Groundwater Elevation in Well BH02 …..........................4-10

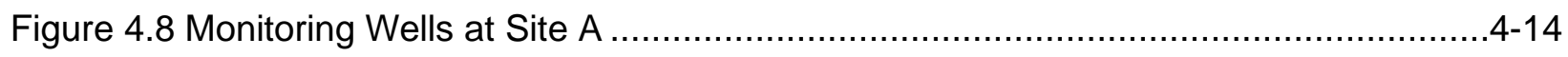

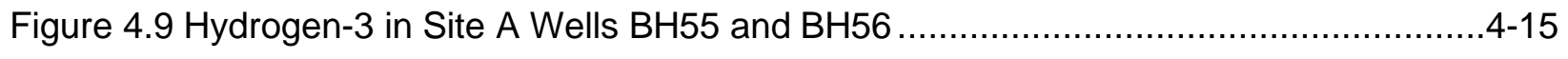

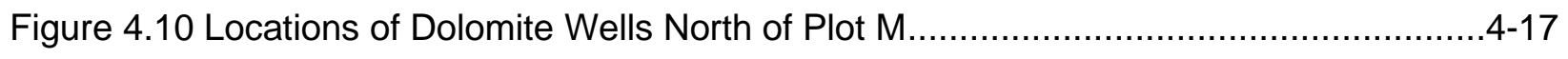

Figure 4.11 Hydrogen-3 Concentrations in Dolomite Well DH15 ...............................4-18

Figure 4.12 Hydrogen-3 in Former Picnic Wells from 1992 Through $2019 \ldots \ldots \ldots \ldots \ldots \ldots \ldots \ldots \ldots .4-22$ 
This page intentionally left blank 


\section{SURVEILLANCE OF SITE A AND PLOT M \\ REPORT FOR 2019}

\subsection{SUMMARY}

The results of the environmental surveillance program conducted at Site A/Plot $M$ for calendar year 2019 are presented within this document. Site A/Plot M is in the Palos Area Preserves, operated by the Forest Preserve District of Cook County. The surveillance program consists of the collection and analysis of surface and groundwater samples to determine the amount of hydrogen-3 and strontium-90 present in the environment within and surrounding the site of the former research facility (Site $A$ ) and waste burial site (Plot M).

The surveillance program was modified in 2015 by the removal of eight groundwater monitoring wells at Site A and Red Gate Woods, and the reduction in the sampling frequency, for all but the Plot $M$ wells, from quarterly to annual. The changes were based on a review of monitoring results compiled over many years. These results indicated that the concentrations of hydrogen-3 and strontium-90 in the wells that were closed were low and consistently trending downward, and further monitoring of these wells was not required.

The 2019 results indicate that, with a few exceptions, the amounts of hydrogen-3 and strontium-90 are slowly decreasing as a result of decay and dilution. The maximum potential radiation dose to a hypothetical resident near Plot $M$ resulting from residual radioactivity in this area was estimated to be $1.6 \mathrm{mrem} / \mathrm{y}$, based upon very conservative assumptions. A more realistic estimate of potential dose is 0.0002 mrem per visit for an occasional park visitor. The maximum potential dose is far below the DOE's allowable dose to the public of $100 \mathrm{mrem} / \mathrm{y}$.

Hydrogen-3 concentrations in surface water in two small intermittent streams that pass by Plot $\mathrm{M}$ were at or below the detection limit of $0.1 \mathrm{nCi} / \mathrm{L}$ upstream of Plot M, increased up to 25.5 $\mathrm{nCi} / \mathrm{L}$ in surface water adjacent to Plot $\mathrm{M}$, and appeared at a maximum of $30.1 \mathrm{nCi} / \mathrm{L}$ downstream of the Plot M. Five samples of surface water were collected from ponds in the vicinity of Site A. None of these ponds contained hydrogen-3 above detection limits. 
Hydrogen-3 continued to be detected, during 2019, in nine wells surrounding Plot $\mathrm{M}$. The results were found to be slowly decreasing and consistent with previous results in seven of the nine monitoring wells. Monitoring well BHO6 had the highest concentrations of hydrogen-3 and the results were higher than the 2018 results. In recent years, the hydrogen- 3 concentrations in this well have increased significantly compared to concentrations found prior to 2009. BH35 continued a trend of increasing hydrogen-3 concentrations which started in 2003. Low levels of strontium-90 were found in groundwater from three of the eight Plot $M$ wells sampled. The strontium-90 results in well BH06 appear to be slightly increasing along with the hydrogen-3 results. The other strontium-90 results are consistent with those measured in the past. All concentrations were below the State of Illinois' Class I Groundwater Quality Standard of 8 pCi/L for strontium-90.

The two wells in the vicinity of Site A were found to contain much lower amounts of hydrogen-3 than the Plot M wells. The amounts present were found to be slowly decreasing and were consistent with past observations. Low levels of strontium-90 were also found in the two wells. All results were below groundwater quality standards. Six deep wells constructed in the dolomite bedrock downgradient of Plot $\mathrm{M}$ were found to contain low levels of hydrogen-3, all below the State of Illinois' Class I Groundwater Quality Standard of $20 \mathrm{nCi} / \mathrm{L}$. The 2019 results were consistent with past findings and demonstrate that hydrogen- 3 concentrations in these wells are slowly decreasing.

Two unused former picnic wells were sampled. Both wells had low levels of hydrogen-3, similar to last year's results. The hydrogen-3 levels in the former picnic well at Red Gate Woods have been increasing slowly since 2010 . The 2019 results were consistent with that trend. All results were below the State of Illinois' Class I Groundwater Quality Standard of 20 nCi/L.

During the May 2018 Annual Inspection, increased erosion was noted along the path from the northeast corner of Plot M heading down towards the creek. Timber steps were installed in 2018 to reduce erosion along the northeast trail. Figures 1.1, 1.2 and 1.3 show views of the new timber steps which have significantly reduced erosion

The results of the surveillance program indicate that the radioactivity remaining at Site A/Plot $M$ does not endanger the health or safety of the public visiting the site, using the picnic areas, or living in the vicinity. 


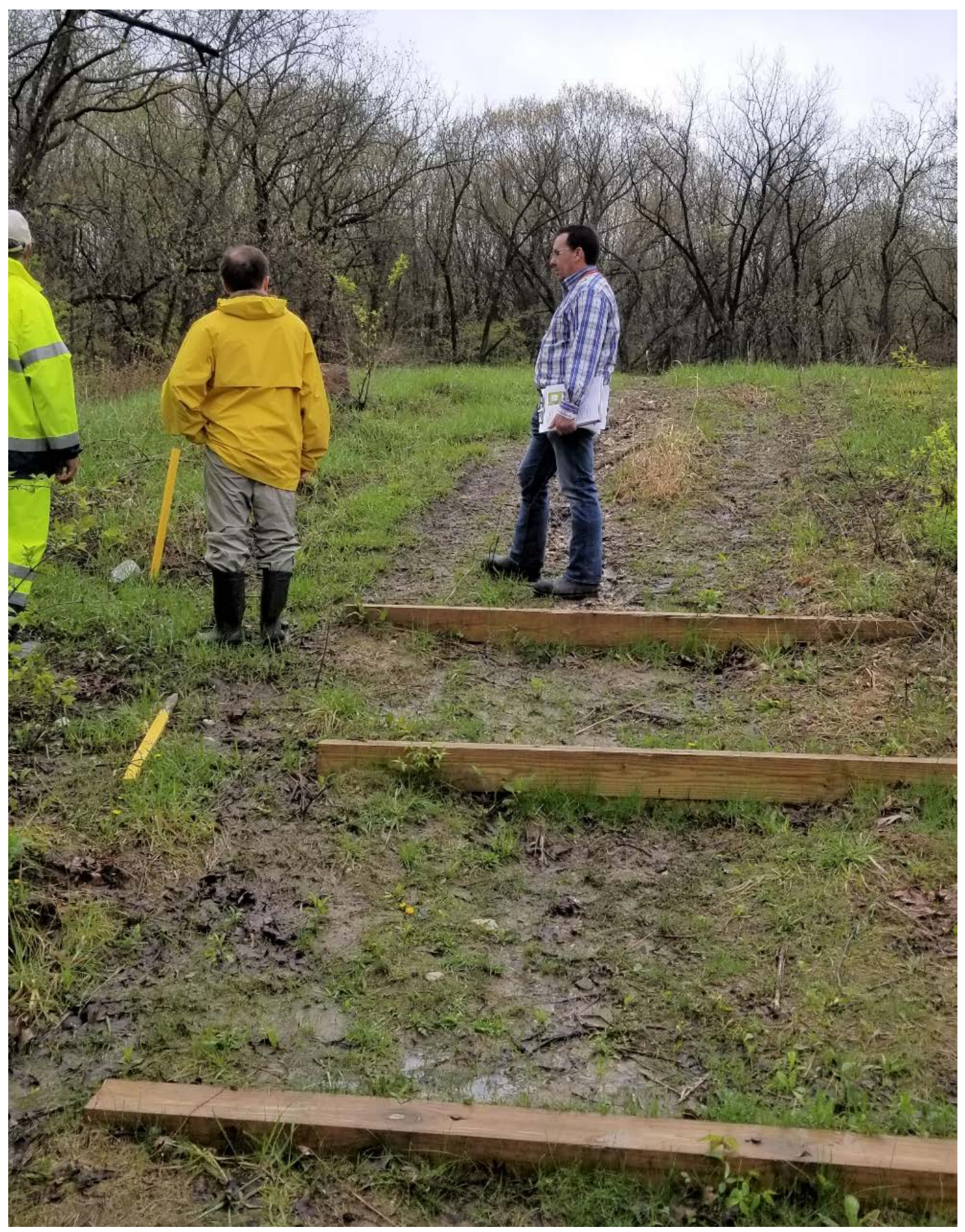

Figure 1.1 View of timber steps installed along northeast path at Plot M 


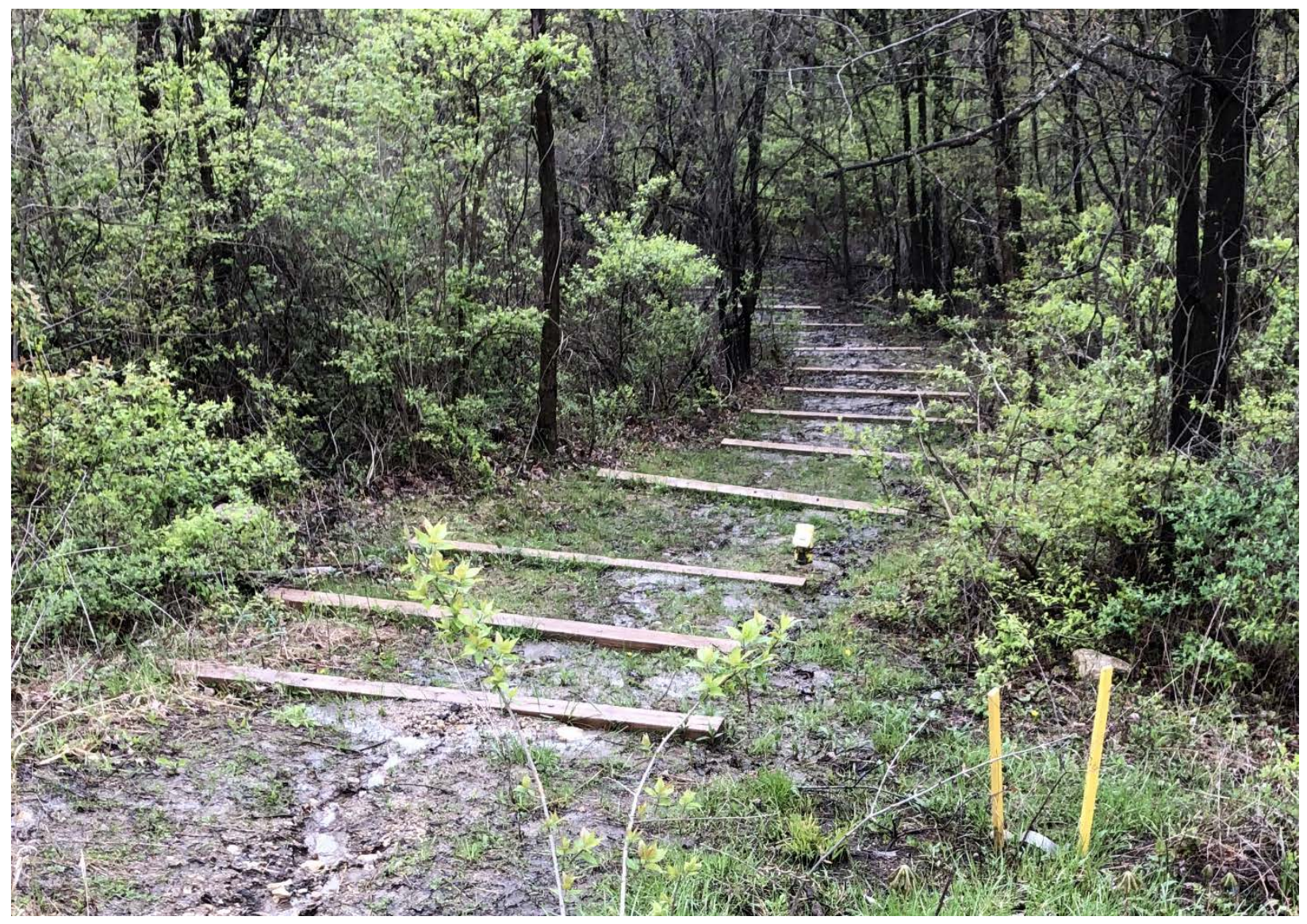

Figure 1.2 Northeast view of timber steps installed along the path at Plot M 


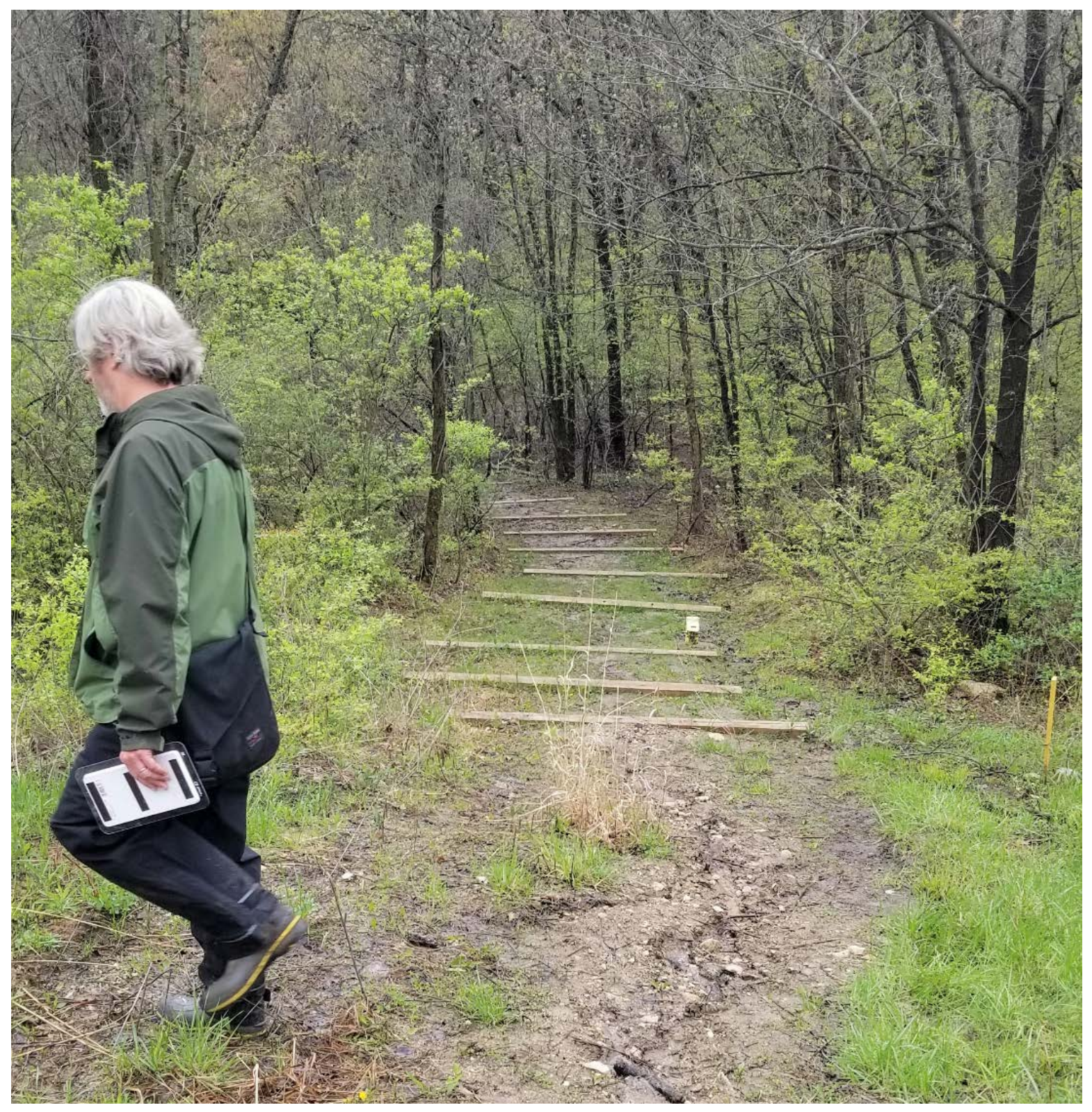

Figure 1.3 North view of timber steps installed along northeast path at Plot M 
This page intentionally left blank 


\section{$2.0 \quad$ INTRODUCTION}

\subsection{Site History}

The environmental surveillance program discussed in this report is an ongoing activity that resulted from the 1976-1978 radiological characterization of the former site of Argonne National Laboratory and its predecessor, the University of Chicago's Metallurgical Laboratory. This site was part of the World War II Manhattan Engineer District Project and was located in a forested area southwest of Chicago, IL, owned by the Forest Preserve District of Cook County, now known as the Palos Area Preserves. Research was conducted at two locations in the Palos Area Preserves: Site A, a 19-acre area that contained experimental laboratories and nuclear reactor facilities; and Plot M, a $150 \mathrm{ft} \times 140 \mathrm{ft}$ area used for the burial of radioactive waste. The location of the Palos Area Preserves is shown in Figure 2.1. The locations of Site A and Plot M are shown in Figure 2.2. Previous comprehensive reports on this subject ${ }^{1,2}$ provide additional detail and illustrations on sampling locations and provide descriptive material along with the results through

1981. Annual reports are available for 1982 through $2018 .^{3-36,54-56}$ While earlier data will not be repeated in this report, reference is made to some of the results.

Operations at Site A began in 1943 and ceased in 1954. Among the research programs carried out at Site A were reactor physics studies, fission product separations, hydrogen-3 recovery from irradiated lithium, and work related to the metabolism of radionuclides in laboratory animals. Radioactive waste and radioactively-contaminated laboratory articles from these studies were buried at Plot $\mathrm{M}$. At the termination of the programs, the reactor fuel and heavy water, used for neutron moderation and reactor cooling, were removed and shipped to Oak Ridge National Laboratory. The biological shield for the CP-3 reactor located at Site A, together with various pipes, valves, and building debris, was buried in place in 1956. 


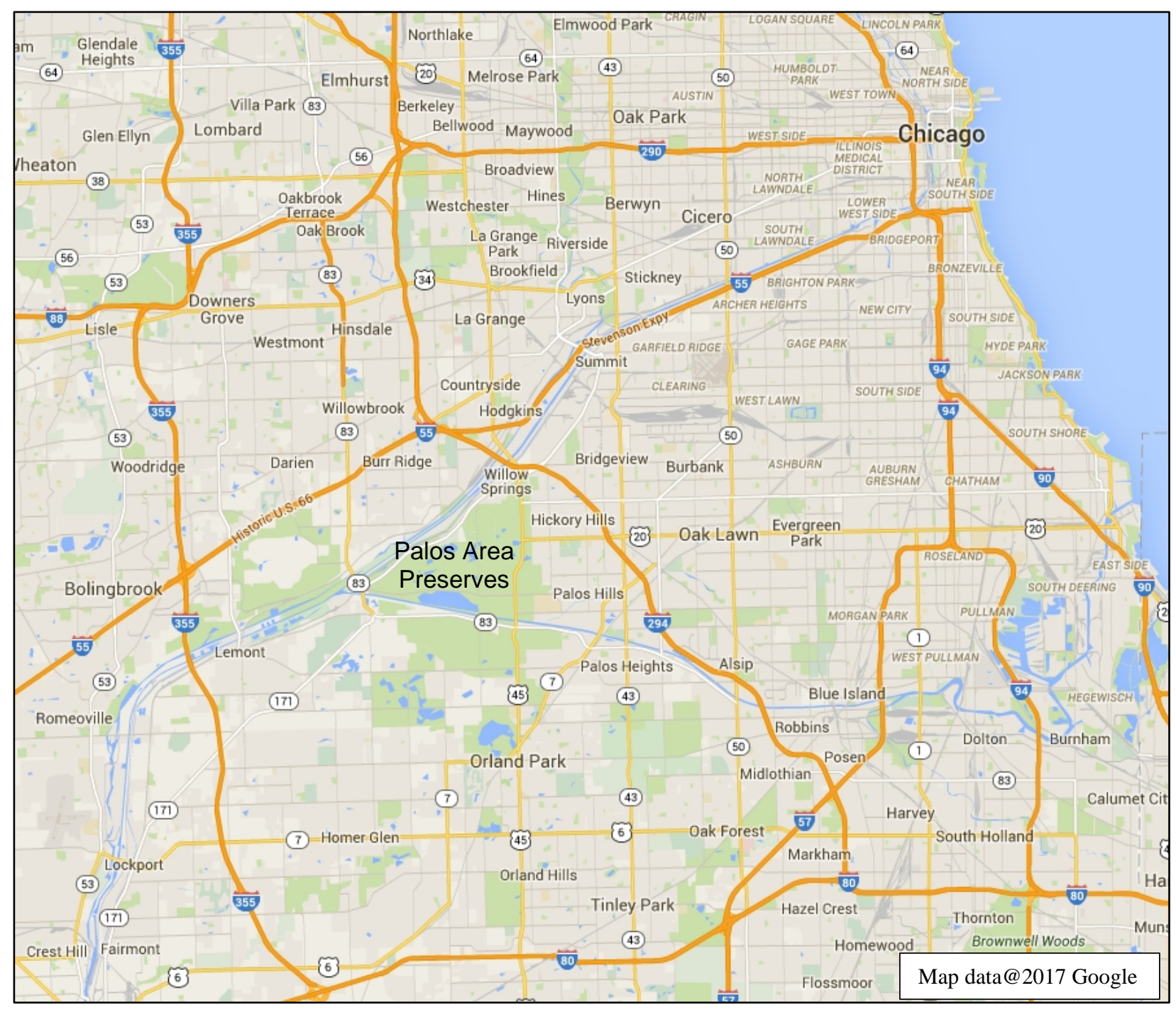

Figure 2.1 Location of Palos Area Preserves 


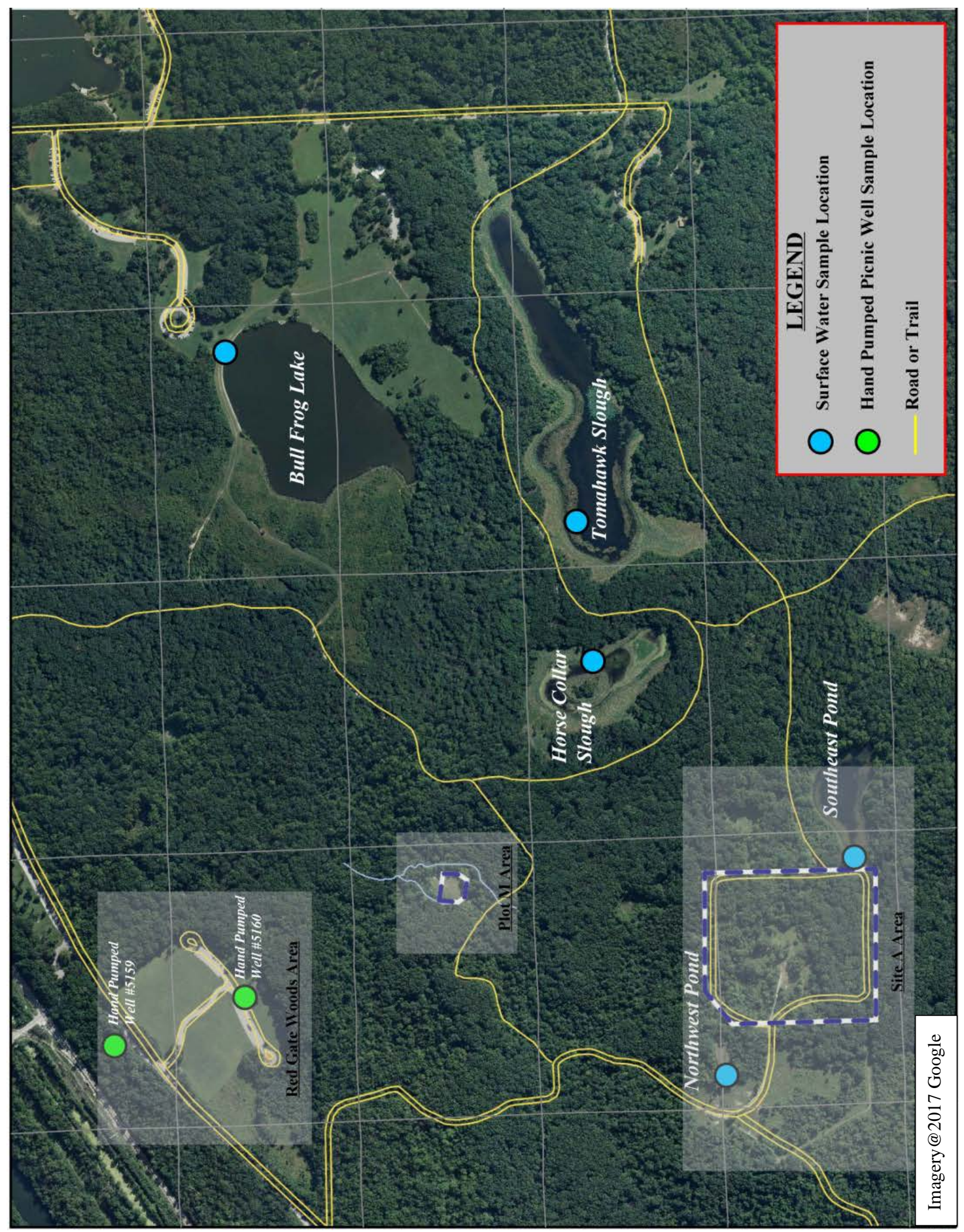

Figure 2.2 Site A/Plot M Area Map 
Burial of radioactive waste at Plot M began in 1944 and was discontinued in 1949. Waste was buried in six-foot deep trenches and covered with soil until 1948, after which burial took place in steel bins. The steel bins were removed in 1949 and sent to Oak Ridge National Laboratory for disposal; however, the waste, buried in trenches, was allowed to remain in place. Concrete sidewalls, eight feet deep, were poured around the perimeter of the burial area and a one-foot thick reinforced concrete slab was poured over the top. The concrete slab was covered with soil and seeded with grass. Both the Site A and Plot M areas were decommissioned in 1956.

In 1973, elevated levels of hydrogen-3 (as tritiated water) were detected by Argonne in two nearby hand-pumped picnic wells (\#5167 and \#5159). Later investigations found the hydrogen-3 to be migrating from the Plot $\mathrm{M}$ burial plot into the surrounding soil and aquifers. As a result, a radiological survey of the area surrounding the site was conducted by Argonne in 1976 with special emphasis on the Site $\mathrm{A}$ and Plot $\mathrm{M}$ areas. ${ }^{1}$

In 1990, elevated levels of radioactivity were discovered outside the original developed area. By 1997, additional characterization and remediation had been completed by DOE to remove residual radioactivity and document the remediation of the area.

The terminology used in previous reports is continued in this report. A hole drilled and well installed into the glacial drift is called a borehole $(\mathrm{BH})$. Water from such wells is called groundwater. Monitoring wells drilled into the dolomite bedrock are called deep holes (DH). The former hand-pumped drinking water wells, which are completed into or close to the dolomite bedrock, are called picnic wells. They are identified by a location name and well number.

The results of radioactivity measurements are expressed in this report in terms of picocuries per liter (pCi/L) for strontium-90 and nanocuries per liter ( $\mathrm{nCi} / \mathrm{L})$ for hydrogen-3 in water samples. The use of the term dose throughout this report means effective dose equivalent. Radiation effective dose equivalent calculations are reported in units of millirem (mrem) or millirem per year $(\mathrm{mrem} / \mathrm{y})$. Other abbreviations of units are defined in the text. 


\section{$2.1 \quad$ Site Characteristics}

Geologically, Plot $\mathrm{M}$ is constructed on a moraine upland which is dissected by two valleys, the Des Plaines River valley to the north and the Calumet Sag valley to the south. The upland is characterized by rolling terrain with poorly developed drainage. Streams are intermittent and drain internally or flow to one of the valleys. The area is underlain by glacial drift, dolomite, and other sedimentary rocks. The uppermost bedrock is Silurian dolomite, into which both the picnic wells and some of the monitoring wells are placed. The dolomite bedrock is about 200 feet thick. The overlying glacial drift has a thickness that ranges from 165 feet at Site $A$ to zero at the Des Plaines River and Calumet Sag Canal, and the boreholes terminate in this layer. The depth to bedrock at Plot $\mathrm{M}$ is about 130 feet.

Hydrologically, the surface water consists of ponds and intermittent streams. When there is enough precipitation, an intermittent stream flows past Plot $\mathrm{M}$, continues near the Red Gate Woods picnic well (\#5160 in Figure 2.2), and discharges into the Illinois and Michigan (I\&M) Canal. The groundwater in the glacial drift and dolomite forms two distinct flow systems. The flow of groundwater in the drift is controlled principally by topography. The groundwater in the dolomite, which is recharged by groundwater migrating downward through the glacial drift, flows toward two discharge areas, the Des Plaines River to the north and the Calumet Sag Canal to the south. There is no groundwater usage downgradient of Site A/Plot M. The former hand-pumped picnic wells have been disabled by removing the handles. These wells are currently used only for groundwater monitoring.

The climate is that of the upper Mississippi valley, as moderated by Lake Michigan, and is characterized by cold winters and hot summers. Precipitation averages about 37 inches annually. The largest rainfalls occur between April and September. The average monthly temperature ranges from $21^{\circ} \mathrm{F}$ in January to $73^{\circ} \mathrm{F}$ in July. Approximately 8.9 million people reside within 50 miles of the site; the population within a five-mile radius is about 150,000 . The only portion of the Palos Area Preserves in the immediate area of Plot $\mathrm{M}$ and Site $\mathrm{A}$ that is developed for public use is the Red Gate Woods picnic area (Figure 2.2), although small numbers of individuals use the trails that pass through more remote areas of the Preserve. 
This page intentionally left blank 


\subsection{MONITORING PROGRAM}

\subsection{Purpose of Monitoring Program}

The monitoring program at Site A/Plot $\mathrm{M}$ was conducted in accordance with the "Long-Term Surveillance and Maintenance Plan for Site A and Plot M, Palos Forest Preserve, Cook County, Illinois", issued in January 2015 37 . DOE-LM conducts stewardship activities at Site A and Plot M to protect human health and the environment, facilitate stakeholder involvement, and to comply with applicable regulations. DOE-LM carries out its stewardship responsibilities through a combination of government ownership, conducting regular inspections, maintaining institutional controls, facilitating public awareness, and monitoring environmental media.

The monitoring program is assessed every three to five years to determine if the goals are being met. At each review, changes to the monitoring program may be recommended. The current monitoring program was put in place by DOE-LM in 2015 following reviews conducted in 2011 (DOE 2011) ${ }^{38}$ and 2014 (DOE 2014) ${ }^{39}$. These reviews found that, with the exception of hydrogen-3 at Plot $\mathrm{M}$, past monitoring results indicated that concentrations of radionuclides were low, and trends were decreasing and consistent. The low concentrations, coupled with the consistent trends, indicated that, with the exception of sampling for hydrogen-3 at Plot $\mathrm{M}$, the major monitoring objectives could be met through annual rather than quarterly sampling. It was found that eight groundwater monitoring wells could be plugged and abandoned without jeopardizing monitoring objectives. These wells were sealed and abandoned, in accordance with Illinois Environmental Protection Agency requirements, in 2015. Four wells were closed at Site A (BH41, BH51, BH52 and BH54). Four deep dolomite wells at Red Gate Woods were also closed (DH09, DH10, DH13, and DH17). The sampling frequency for the remaining wells at Site $A$ and Red Gate Woods, and including the two picnic wells and five ponds near Site A and Plot M, were reduced from quarterly to annual in 2015. The sampling program for Plot $M$ was not changed and remains on a quarterly schedule. The constituents of concern in groundwater and surface water continued to be limited to hydrogen-3 and strontium-90. 


\subsection{Structure of Monitoring Program}

The Site A/Plot $M$ monitoring program follows the guidance for monitoring at DOE facilities. ${ }^{40}$ Although Site A/Plot $M$ is not an active DOE facility, the same monitoring principles are applicable. The monitoring program is designed to assess the concentration of hydrogen-3 and strontium-90 in groundwater near these sites, and to monitor hydrogen-3 in two of the former picnic wells in Red Gate Woods and several surface water bodies in the vicinity. This is accomplished by analyzing water collected from wells and surface water. Sampling locations are described in the following sections of this report. Samples collected, analyses performed, and the sampling frequency are shown in Table 3-1.

The samples were analyzed by the Argonne QAS Division Analytical Services radiochemistry laboratories using DOE-approved methods. The detection limits for hydrogen-3 in water is $0.1 \mathrm{nCi} / \mathrm{L}$ and $0.25 \mathrm{pCi} / \mathrm{L}$ for strontium-90 in water. The uncertainties associated with individual concentrations for strontium-90 shown in the tables are the statistical counting errors at the $95 \%$ confidence level. Because of the amount of hydrogen-3 data presented in many of the tables, the uncertainty values are not included. In such cases, the following typical uncertainties apply:

Hydrogen-3 Concentration (nCi/L)

0.1-1.0

1-10

$>10$
Uncertainty (\% of Conc.)

40-5\%

5-1\%

$1 \%$ 
Table 3.1 Environmental Monitoring Program for Site A and Plot M

\begin{tabular}{|c|c|c|}
\hline Location name & Frequency - Hydrogen-3 & Frequency - Strontium-90 \\
\hline \multicolumn{3}{|c|}{ Site A - Groundwater from monitoring wells in glacial drift } \\
\hline $\mathrm{BH} 55$ & Annual & Annual \\
\hline $\mathrm{BH} 56$ & Annual & Annual \\
\hline \multicolumn{3}{|c|}{ Site $A$ region - surface water ponds } \\
\hline Northwest Pond & Annual & NSR \\
\hline Southeast Pond & Annual & NSR \\
\hline Bull Frog Lake & Annual & NSR \\
\hline Horse Collar Slough & Annual & NSR \\
\hline Tomahawk Slough & Annual & NSR \\
\hline \multicolumn{3}{|c|}{ Plot M - Groundwater from monitor wells in glacial drift } \\
\hline $\mathrm{BH} 02$ & Quarterly & Annual \\
\hline $\mathrm{BH} 03$ & Quarterly & Annual \\
\hline $\mathrm{BH} 04$ & Quarterly & Annual \\
\hline $\mathrm{BH} 06$ & Quarterly & Annual \\
\hline $\mathrm{BH} 09$ & Quarterly & Annual \\
\hline $\mathrm{BH} 10$ & Quarterly & Annual \\
\hline $\mathrm{BH} 11$ & Quarterly & Annual \\
\hline $\mathrm{BH} 26$ & Quarterly & Annual \\
\hline $\mathrm{BH} 35$ & Quarterly & Annual \\
\hline \multicolumn{3}{|c|}{ Red Gate Woods - Groundwater from monitor wells in dolomite } \\
\hline $\mathrm{DHO3}$ & Annual & NSR \\
\hline $\mathrm{DH} 04$ & Annual & NSR \\
\hline $\mathrm{DH} 11$ & Annual & NSR \\
\hline $\mathrm{DH} 12$ & Annual & NSR \\
\hline $\mathrm{DH} 14$ & Annual & NSR \\
\hline $\mathrm{DH} 15$ & Annual & NSR \\
\hline \multicolumn{3}{|c|}{ Red Gate Woods - Groundwater from former picnic wells in dolomite } \\
\hline 5159 & Annual & NSR \\
\hline 5160 & Annual & NSR \\
\hline \multicolumn{3}{|l|}{ Plot M - Surface Water } \\
\hline Location 1 & Quarterly & NSR \\
\hline Location 6 & Quarterly & NSR \\
\hline Location 7 & Quarterly & NSR \\
\hline Location 8 & Quarterly & NSR \\
\hline
\end{tabular}

NSR = No Sample Required 
This page intentionally left blank 


\subsection{RESULTS OF THE MONITORING PROGRAM}

During 2019, all planned samples were collected, with the exception of the Plot M stream samples during the third quarter. Monitoring results are presented in the following sections of this report.

\subsection{Plot M Surface Water}

Surface water samples were attempted to be collected quarterly from four sampling locations along the two streams that flow around Plot $M$, shown in Figure 4.1. Location 1 is upstream of the Plot M area. Location 6 is immediately north and downstream of Plot M. No water was present in the stream bed during the third quarter of 2019 , thus no surface water samples were collected from these locations. During the 2017 DOE-LM site visit, it was decided that because the stream flow is intermittent, Location 6 sample would only be collected when flowing water is present. During quarter three, attempts were made to collect stream samples from Plot $\mathrm{M}$ after a significant precipitation event. Despite the attempts, insufficient flow was present for collecting a sample.

The stream samples were analyzed for hydrogen-3 and the results are shown in Table 4.1. The same concentration pattern in the water flowing around Plot $\mathrm{M}$ was observed this year as in the past. Concentrations were below the detection limit upstream of Plot M (Location 1); hydrogen-3 was the highest at Location 7 during the fourth quarter. Historically, the lower concentrations were found downstream of Plot M (Locations $7 \& 8$ ). The amount of hydrogen-3 at Location 6 in the April sample was $25.5 \mathrm{nCi} / \mathrm{L}$. The other surface water samples collected during 2019 were comparable to concentrations observed in recent years.

Historically surface water location \#6 was identified as a seep. Over time, erosion patterns in the shallow streambed near location \#6 created low spots for water to remain in-between precipitation events. Quarterly samples were then subsequently collected from these low spots. It was determined that the integrity of the seep be distinguished as flowing or non-flowing. In January 2017, a site visit to Plot M was performed after several days of below freezing conditions to verify flow at surface water location \#6 (seep \#6). No ice/water mounding was observed along the slope wall in the vicinity of location \#6 (seep \#6). Due to the lack of flow at the vicinity of the seep, it was determined to reclassify the location as Surface Water Location \#6 and remove the seep designation. 


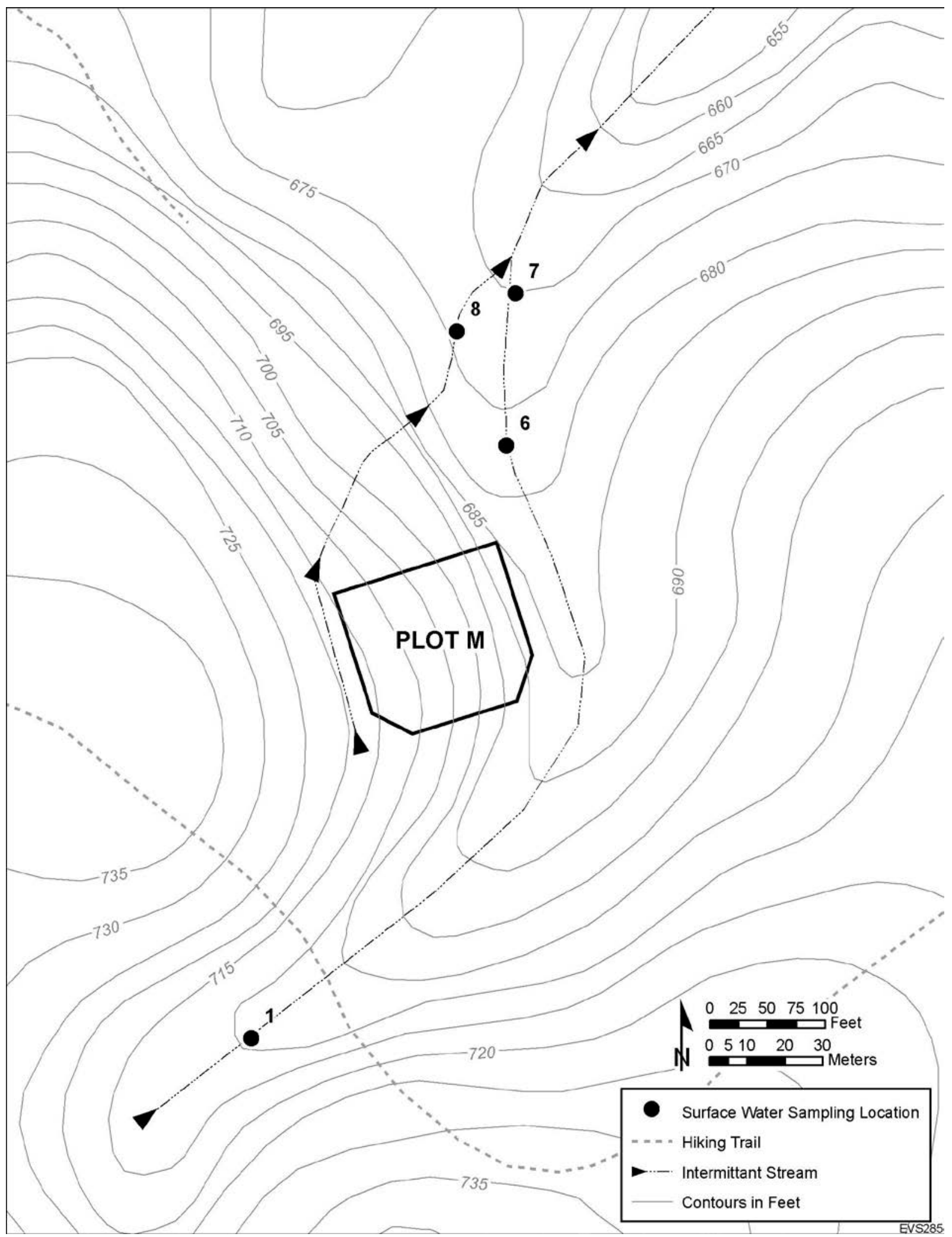

Figure 4.1 Stream Sampling Locations near Plot M 
Table 4.1 Hydrogen-3 Content of Stream Next to Plot M, 2019

\begin{tabular}{crccc}
\hline & \multicolumn{4}{c}{$\begin{array}{c}\text { Date Collected } \\
\text { (Concentrations in nCi/L) }\end{array}$} \\
\cline { 2 - 5 } Number $^{1}$ & March 14 & April 30 & Q3 & December 12 \\
\hline 1 & $<0.1$ & $<0.1$ & DRY & $<0.1$ \\
6 & 2.1 & 25.5 & DRY & DRY \\
7 & 0.96 & 4.1 & DRY & 30.1 \\
8 & 0.18 & 0.57 & DRY & 9.2 \\
\hline
\end{tabular}

${ }^{1}$ See Figure 4.1

Hydrogen-3 concentrations in the streams vary greatly, depending in part on the amount of precipitation prior to sample collection. Some of the previous years' samples from Locations 7 and 8 had higher than normal hydrogen-3 concentrations. In previous years, samples were collected during times of very low flow in the streams due to dry weather prior to the sampling event. The low flow conditions could have resulted in surface water with higher contribution of groundwater emanating from the Plot $\mathrm{M}$ area, resulting in higher than normal hydrogen-3 concentrations. This also allows for a more conservative risk assessment of human health and the environment.

During the Fall of 2019, site visits were conducted during precipitation events to observe stream flow, but there was not enough flowing water to collect samples.

One set of samples from five surface water bodies in the vicinity of Site A was collected in June of 2019. They are the pond northwest of Site A; the pond southeast of Site A; Horse Collar Slough; Tomahawk Slough; and Bull Frog Lake. These locations are identified in Figure 2.2. The samples were analyzed for hydrogen-3 and the results are presented in Table 4.2. All of the hydrogen-3 results were below the detection limit of $0.1 \mathrm{nCi} / \mathrm{L}$. 
Table 4.2 Hydrogen-3 Content of Site A Area Ponds, 2019

\begin{tabular}{lc}
\hline \multicolumn{1}{c}{ Location } & $\begin{array}{c}\text { June } 18 \\
\text { (Concentrations in nCi/L) }\end{array}$ \\
\hline NW Site A & $<0.1(<0.1)$ \\
SE Site A & $<0.1$ \\
Bull Frog Lake & $<0.1$ \\
Horsecollar Slough & $<0.1$ \\
Tomahawk Slough & $<0.1(<0.1)$ \\
\hline
\end{tabular}

\subsection{Plot M Groundwater}

Nine monitoring wells screened within the glacial drift are present in and around Plot M (Figure 4.2). Two of these wells (BH09 and $\mathrm{BH} 10$ ) were drilled at a $45^{\circ}$ angle to intercept groundwater under the waste. Water samples were collected in all nine wells and water level measurements were recorded quarterly in seven wells. The water levels for the angle wells was not measured. Due to low water volume in $\mathrm{BH} 35$ during the third quarter, an insufficient volume was obtained for strontium-90 analysis.

All of the water samples were analyzed for hydrogen-3; the results are shown in Table 4.3. Duplicate quality control sample results are shown in parentheses. The hydrogen-3 concentrations varied widely from well to well and in some cases from quarter to quarter. The magnitudes of the hydrogen-3 concentrations are similar to those observed over the past several years. Most of the results indicate that hydrogen-3 concentrations are slowly decreasing in these wells. 


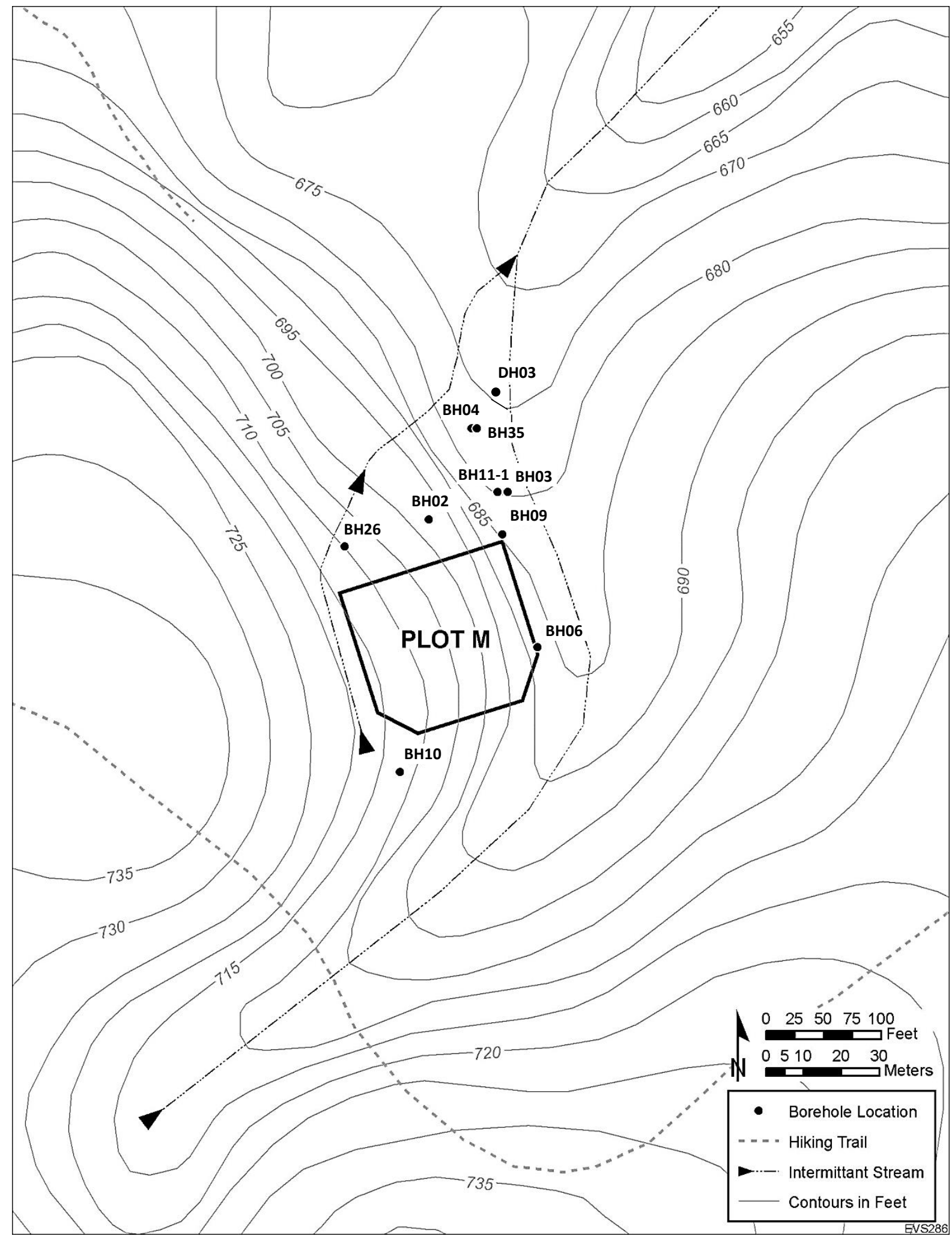

Figure 4.2 Map of Plot M Site 
Table 4.3 Hydrogen-3 Content of Plot M Monitoring Well Water, 2019

\begin{tabular}{cccccc}
\hline \multirow{2}{*}{$\begin{array}{c}\text { Borehole } \\
\text { Number }\end{array}$} & $\begin{array}{c}\text { Well } \\
\text { Depth } \\
\text { (ft) }\end{array}$ & \multicolumn{5}{c}{$\begin{array}{c}\text { Date Collected } \\
\text { (Concentrations in nCi/L) }\end{array}$} \\
\cline { 3 - 6 } BH02 & 39.41 & March 27 & June 19 & September 18 & December 12 \\
BH03 & 40.00 & $84(74)$ & 6.3 & $6.5(6.6)^{1}$ & 6.8 \\
BH04 & 36.05 & 306 & 296 & 8.1 & 0.2 \\
BH06 & 40.30 & 309 & 5,693 & 3,077 & $304(300)$ \\
BH09 & $40.00^{2}$ & 875 & 551 & 284 & 923 \\
BH10 & $40.00^{2}$ & 12 & 13 & 29 & 13 \\
BH11-1 & 39.30 & 51 & 53 & 62 & 59 \\
BH26 & 60.65 & 6.1 & 3.9 & 62 & 3.9 \\
BH35 & 105.50 & 748 & 746 & 737 & 753 \\
\hline
\end{tabular}

${ }^{1}$ Duplicate QC sample results are denoted in parentheses.

${ }^{2}$ Slant hole drilled at $45^{\circ}$ to a depth of $40 \mathrm{ft}$. below the surface.

The highest hydrogen-3 concentrations near Plot M during 2019 were found in $\mathrm{BH} 04$, $\mathrm{BH} 06, \mathrm{BH} 35$, and the slant well $\mathrm{BH} 09$. Figure 4.3 shows the trend in hydrogen- 3 concentrations in $\mathrm{BHO}$ and $\mathrm{BH} 04$. Since 1989, there has been a steady decrease in hydrogen-3 concentration in these wells. Figure 4.4 shows the trend of hydrogen-3 concentrations in $\mathrm{BH} 09$, a slant well with the well screen located directly under Plot $\mathrm{M}$. This well had very high levels of hydrogen-3 during the 1990s, and have since significantly decreased. Since 1999, the hydrogen-3 concentrations have steadily decreased. 


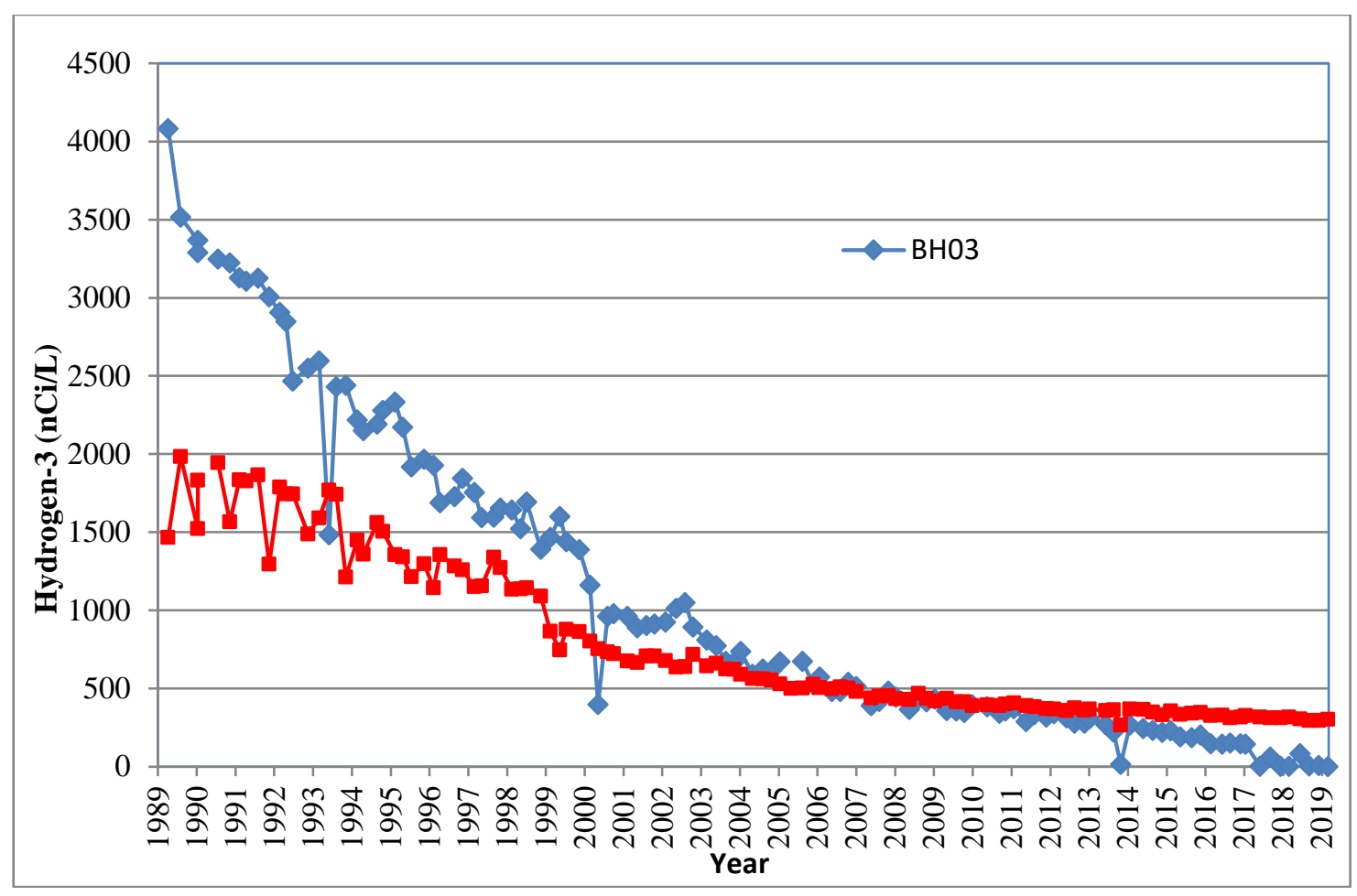

Figure 4.3 Hydrogen-3 in Plot M Wells BH03 and BH04

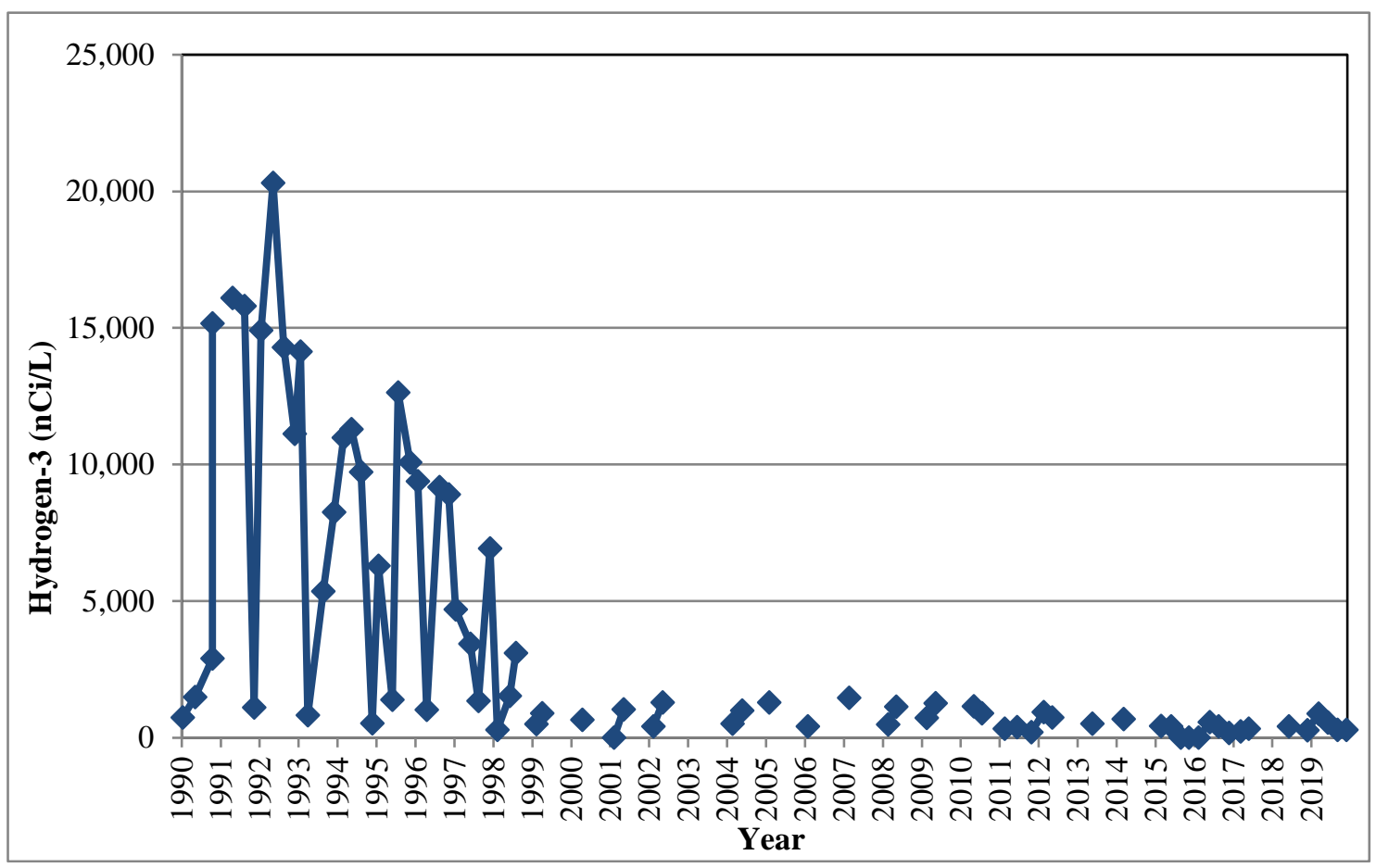

Figure 4.4 Hydrogen-3 in Plot M Well BH09 
As shown in Table 4.3, Well BH06 contained high hydrogen-3 concentrations during all four quarters of 2019 , with the second quarter of 2019 being the highest. The trend in hydrogen-3 concentrations in $\mathrm{BHO6}$ since 1989 is shown in Figure 4.5, which also depicts groundwater elevations in this well. From 1994 through the first half of 2009, the hydrogen-3 concentrations ranged from 50 to $150 \mathrm{nCi} / \mathrm{L}$. Beginning in 2009, hydrogen-3 concentrations increased, reaching values as high as 1,534 nCi/L in 2011, $488 \mathrm{nCi} / \mathrm{L}$ in 2012, $748 \mathrm{nCi} / \mathrm{L}$ in 2013, 3,035 nCi/L in 2014, $1,223 \mathrm{nCi} / \mathrm{L}$ in 2015, 1,360 nCi/L in 2016 and 1,040 nCi/L in 2017, 1,325 nCi/L in 2018 and 5,693 $\mathrm{nCi} / \mathrm{L}$ in 2019. During this time period, groundwater elevations were found to have fluctuated more than during the period between 1994 and 2009. The changing groundwater elevations could be responsible for the recent increase in hydrogen-3 concentrations and the wide variability between sample results.

Well BH35 hydrogen-3 concentrations, shown in Figure 4.6, have been steadily increasing since 2003. The cause of the increase is related to downward movement of the hydrogen-3 plume beneath Plot M to the northeast towards the Des Plaines River. Well BH35 is the deepest at 105 feet and downgradient of Plot $\mathrm{M}$.

Figure 4.7 shows hydrogen-3 concentrations in Well BH02 since 1990. The hydrogen-3 concentrations in this well remained at low levels during 2019, as compared to 2012 and 2013, which had several samples with relatively high levels of hydrogen-3. This figure also shows the groundwater elevation in the well. Figure 4.7 indicates that the spikes in hydrogen-3 concentration that occurred in previous years happened during periods when the groundwater elevation was lower than normal. Lower groundwater elevations could change the way groundwater moves and interacts with contaminated soil under Plot $\mathrm{M}$, causing the hydrogen-3 concentrations to vary widely. 


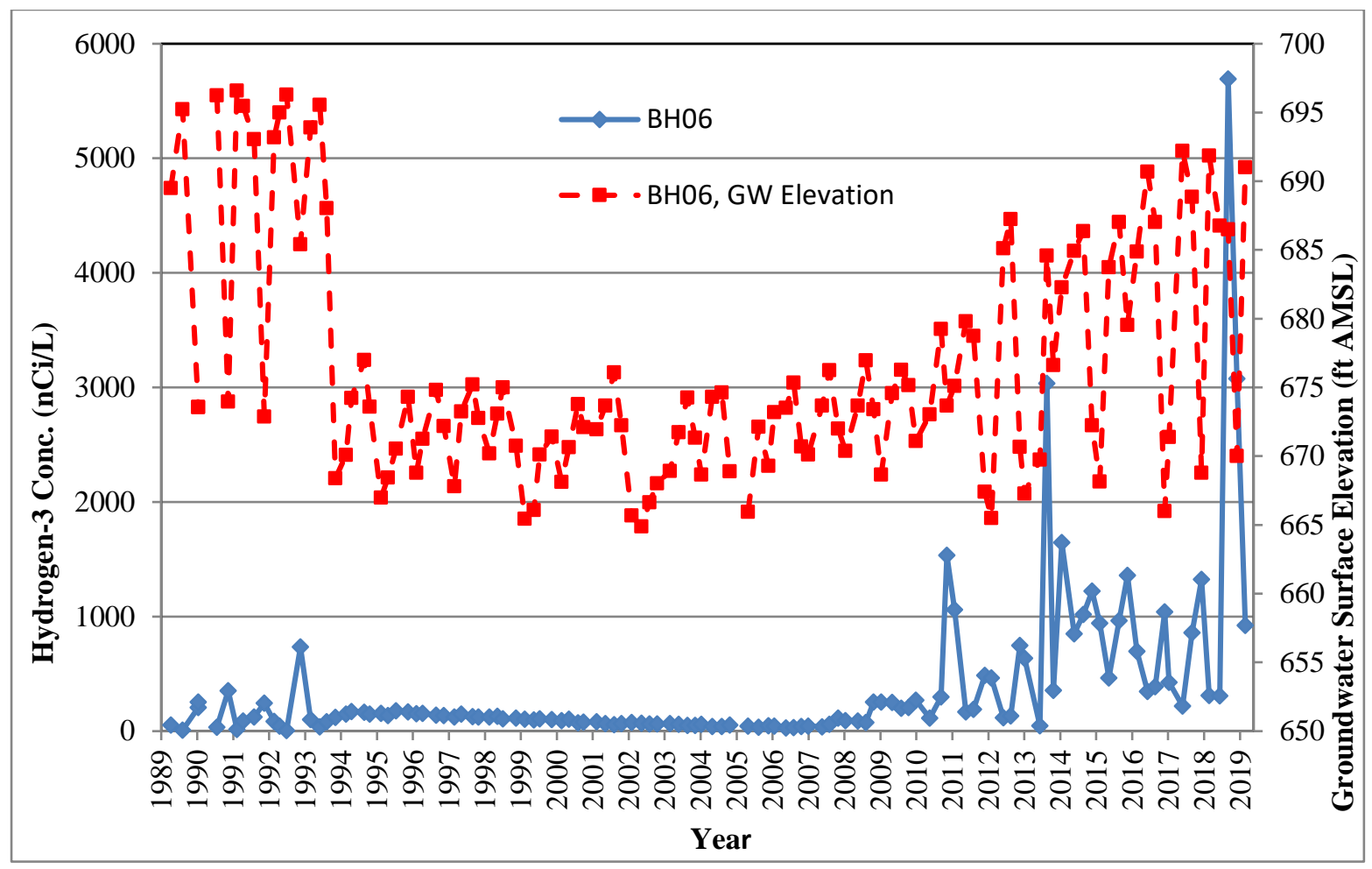

Figure 4.5 Hydrogen-3 and Groundwater Elevation in Well BH06

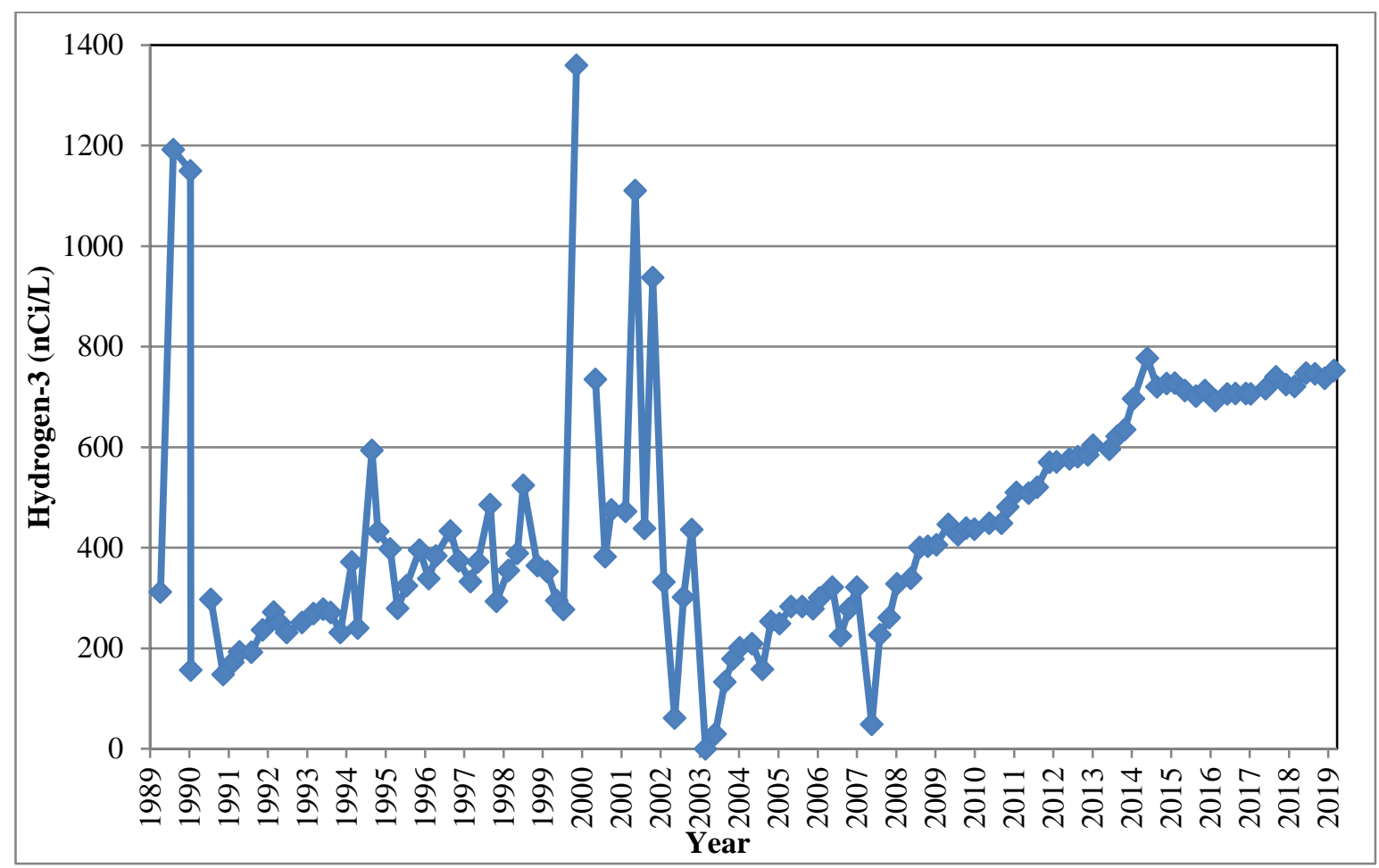

Figure 4.6 Hydrogen-3 in Well BH35 


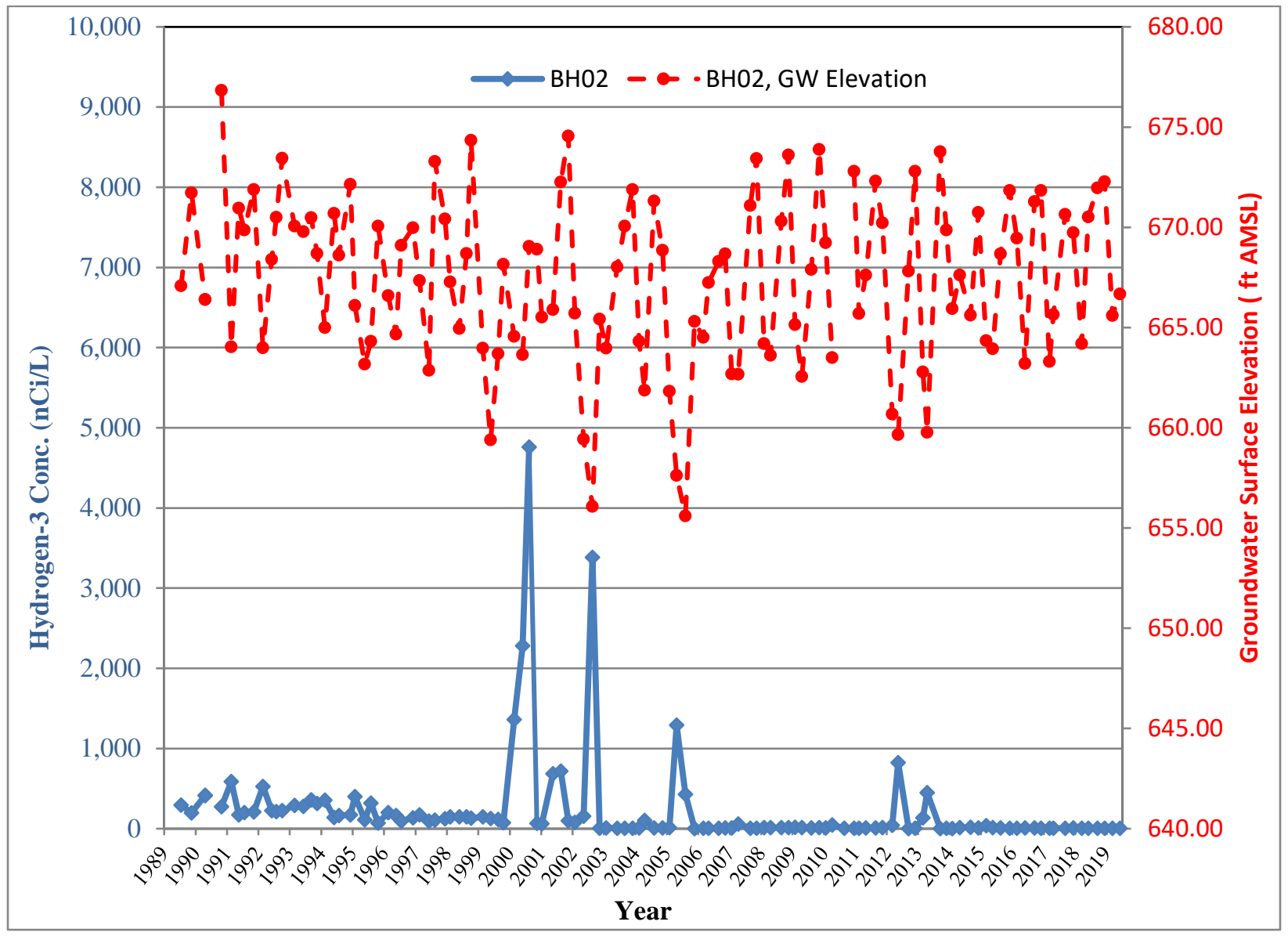

Figure 4.7 Hydrogen-3 and Groundwater Elevation in Well BH02

Groundwater samples from the Plot M monitoring wells were analyzed once for strontium-90 during 2019. The results are shown in Table 4.4. Strontium-90 concentrations greater than the detection limit of $0.25 \mathrm{pCi} / \mathrm{L}$ were found in three of the nine sampled wells. The highest strontium-90 concentration in 2019 was 6.2 pCi/L in water collected from BH09, the slant well screened under the Plot M cap. The concentrations found in 2019 were similar to previous results for this well. Strontium-90 concentrations in well BH06 were also elevated. The concentrations of strontium-90 in this well have been slowly increasing since 2010. All results were less than the State of Illinois Class 1 Ground Water Quality Standard of 8 pCi/L for strontium-90. 
Table 4.4 Strontium-90 Content of Monitoring Well Water Samples Near Plot M, 2019

\begin{tabular}{ccc}
\hline $\begin{array}{c}\text { Well } \\
\text { Number }\end{array}$ & $\begin{array}{c}\text { Well Depth } \\
(\mathrm{ft} .)\end{array}$ & $\begin{array}{c}\text { June } 19 \\
\text { (Concentrations in pCi/L) }\end{array}$ \\
\hline BH02 & 39.41 & $<0.25$ \\
BH03 & 40.00 & $<0.25$ \\
BH04 & 36.05 & $<0.25^{3}$ \\
BH06 & 40.30 & $2.59 \pm 0.210$ \\
BH09 & $40.00^{2}$ & $6.21 \pm 0.490$ \\
BH10 & $40.00^{2}$ & $<0.25^{4}$ \\
BH11-1 & 39.30 & $1.21 \pm 0.101$ \\
BH26 & 60.65 & $<0.25$ \\
BH35 & 105.50 & $\mathrm{NA}^{5}$ \\
\hline
\end{tabular}

1 See Figure 4.2

$2 \mathrm{BH} 09$ and $\mathrm{BH} 10$ are slant wells.

${ }^{3}$ BH04 was analyzed each quarter for Sr-90 and Cs-137 as part of the intercomparison program with the IEMA laboratory. All samples collected during 2019 were $<0.25 \mathrm{pCi} / \mathrm{L}$.

${ }^{4} \mathrm{BH} 10$ was analyzed each quarter for $\mathrm{Sr}-90$ and Cs-137 as part of the intercomparison program with the IEMA. The results for quarters one, two, three and four were $<0.25 \mathrm{pCi} / \mathrm{L}$.

5 No sample due to low water volume at time of collection.

The depth-to-groundwater and groundwater elevations in the vertical wells at Plot $\mathrm{M}$ are shown in Table 4.5. Groundwater elevations measured during 2019 in most of the shallow wells were consistent with typical groundwater elevations in these wells. The water level in $\mathrm{BH} 35$, the $105 \mathrm{ft}$. deep drift well, remained constant throughout the year. Groundwater elevations for the two slant wells are not included in this table since the angle of the well distorts the depth-togroundwater values. Due to the difference in the screen depth of these wells, data could not be used to develop groundwater elevation contour maps of this area. The differing well depths, in addition to the groundwater elevation differences between nearby wells, indicate that a hydraulic connection between the wells cannot be assumed. In general, Plot M groundwater flows downward and downgradient to the northeast, toward the Des Plaines River. 
Table 4.5 Water Level Measurements in Monitoring Wells Near Plot M, 2019

\begin{tabular}{|c|c|c|c|c|c|c|c|c|c|c|}
\hline \multirow[b]{3}{*}{$\begin{array}{c}\text { Well } \\
\text { Number }^{1}\end{array}$} & \multirow[b]{3}{*}{$\begin{array}{l}\text { Depth } \\
\text { (ft.) }\end{array}$} & \multirow[b]{3}{*}{$\begin{array}{l}\text { Top of } \\
\text { Casing } \\
\text { Elevation } \\
(\mathrm{ft} \mathrm{AMSL})^{2}\end{array}$} & \multicolumn{8}{|c|}{ Date Measured } \\
\hline & & & \multicolumn{2}{|c|}{ March 27} & \multicolumn{2}{|c|}{ June 19} & \multicolumn{2}{|c|}{ September 18} & \multicolumn{2}{|c|}{ December 12} \\
\hline & & & $\begin{array}{l}\text { Depth } \\
\text { to } \\
\text { water } \\
\text { (ft.) }\end{array}$ & $\begin{array}{c}\text { Water } \\
\text { Surface } \\
\text { Elevation } \\
\text { (ft AMSL) }\end{array}$ & $\begin{array}{l}\text { Depth } \\
\text { to } \\
\text { water } \\
\text { (ft.) }\end{array}$ & $\begin{array}{c}\text { Water } \\
\text { Surface } \\
\text { Elevation } \\
\text { (ft AMSL) }\end{array}$ & $\begin{array}{l}\text { Depth } \\
\text { to } \\
\text { water } \\
\text { (ft.) }\end{array}$ & $\begin{array}{c}\text { Water } \\
\text { Surface } \\
\text { Elevation } \\
\text { (ft AMSL) }\end{array}$ & $\begin{array}{l}\text { Depth } \\
\text { to } \\
\text { water } \\
\text { (ft.) }\end{array}$ & $\begin{array}{c}\text { Water } \\
\text { Surface } \\
\text { Elevation } \\
\text { (ft AMSL) }\end{array}$ \\
\hline $\mathrm{BH} 2$ & 39.41 & 692.70 & 20.73 & 671.97 & 20.42 & 672.28 & 27.10 & 665.60 & 26.02 & 666.68 \\
\hline $\mathrm{BH} 3$ & 40 & 693.30 & 28.87 & 664.43 & 17.41 & 675.89 & 29.40 & 663.90 & 34.50 & 658.80 \\
\hline $\mathrm{BH} 4$ & 36.05 & 682.20 & 13.42 & 668.78 & 12.60 & 669.60 & 18.23 & 663.97 & 20.45 & 661.75 \\
\hline $\mathrm{BH} 6$ & 40.3 & 704.90 & 18.14 & 686.76 & 18.40 & 686.50 & 34.90 & 670.00 & 13.90 & 691.00 \\
\hline $\mathrm{BH} 11-1$ & 39.3 & 693.00 & 22.42 & 670.58 & 19.75 & 673.25 & 24.75 & 668.25 & 25.10 & 667.90 \\
\hline $\mathrm{BH} 26$ & 60.65 & 692.30 & 43.37 & 648.93 & 56.85 & 635.45 & 42.15 & 650.15 & 38.20 & 654.10 \\
\hline BH35 & 105.5 & 682.40 & 93.22 & 589.18 & 92.25 & 590.15 & 92.95 & 589.45 & 93.43 & 588.97 \\
\hline
\end{tabular}

1 Water depth for wells 09 and 10 are not shown since these are slant wells.

2 From 1994 IT Study report. AMSL = Above mean sea level. 


\subsection{Site A Groundwater}

The locations of the two Site A monitoring wells are shown in Figure 4.8. Hydrogen-3 monitoring results are shown in Table 4.6. The results of duplicate QC samples are shown in parentheses. The results found in water from wells BH55 and BH56 are most likely originating in the buried CP-3 biological shield. The hydrogen-3 concentrations at Site A are several orders of magnitude lower than Plot $\mathrm{M}$, and are decreasing. Figure 4.9 shows the decreasing hydrogen-3 concentrations in these two wells. The results of the strontium-90 analyses are shown in Table 4.7. Groundwater levels were measured in these monitoring wells, and the values appear in Table 4.8.

Table 4.6 Hydrogen-3 Content of Monitoring Well Water Samples Near Site A, 2019

\begin{tabular}{ccc}
\hline $\begin{array}{c}\text { Well } \\
\text { Number }\end{array}$ & $\begin{array}{c}\text { Depth } \\
\text { (ft.) }\end{array}$ & $\begin{array}{c}\text { June } 19 \\
\text { (Concentrations in } \mathrm{nCi} / \mathrm{L})\end{array}$ \\
\hline BH55 & 87.20 & 0.71 \\
BH56 & 102.40 & 1.71 \\
\hline
\end{tabular}

Table 4.7 Strontium-90 Content of Monitoring Well Water Samples Near Site A, 2019

\begin{tabular}{ccc}
\hline $\begin{array}{c}\text { Borehole } \\
\text { Number }\end{array}$ & $\begin{array}{c}\text { Depth } \\
(\mathrm{ft} .)\end{array}$ & $\begin{array}{c}\text { June 19 } \\
\text { (Concentrations in pCi/L) }\end{array}$ \\
\hline BH55 & 87.20 & $0.68 \pm 0.069$ \\
BH56 & 102.40 & $0.93 \pm 0.085$ \\
\hline
\end{tabular}




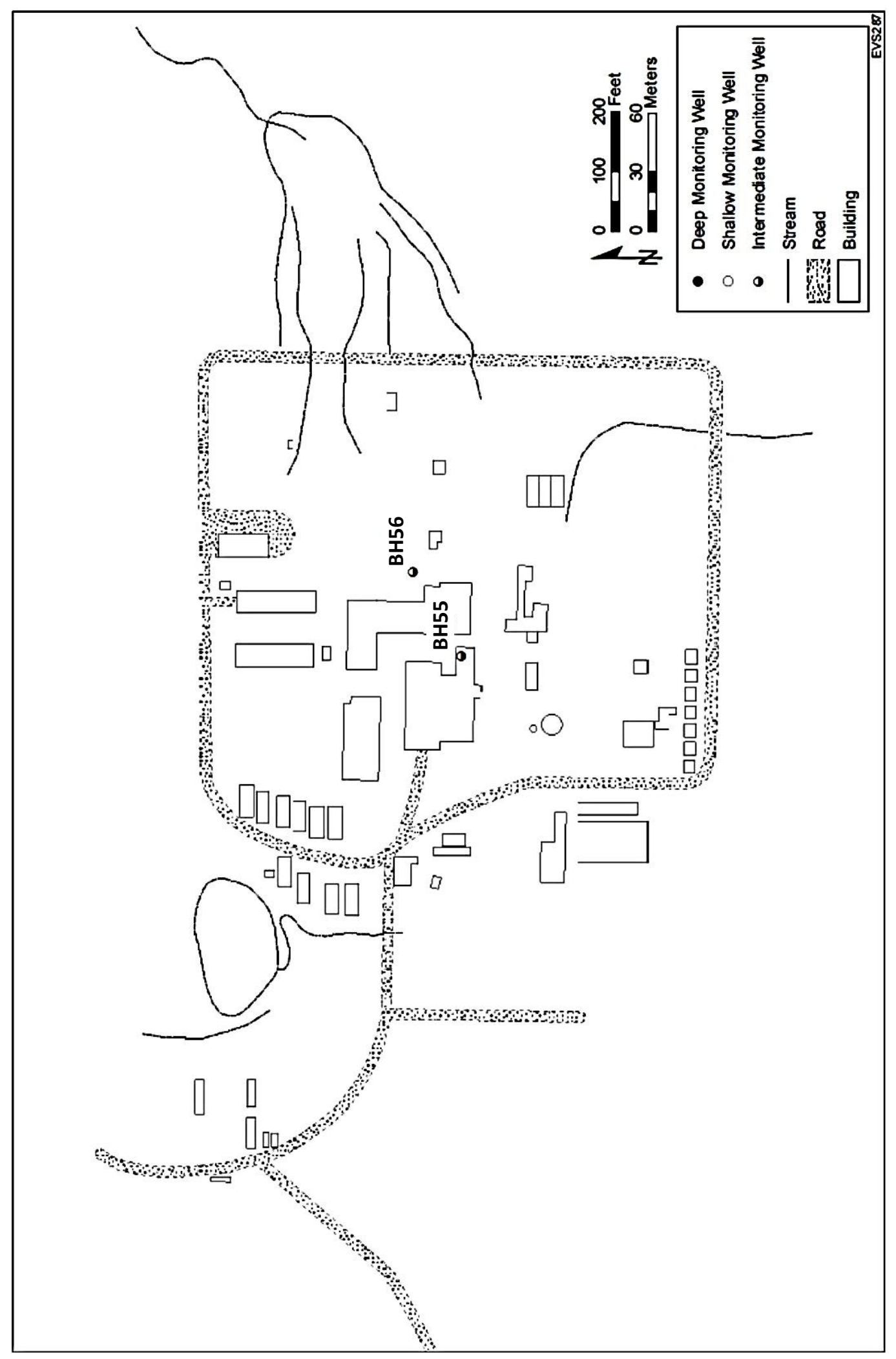

Figure 4.8 Monitoring Wells at Site A 


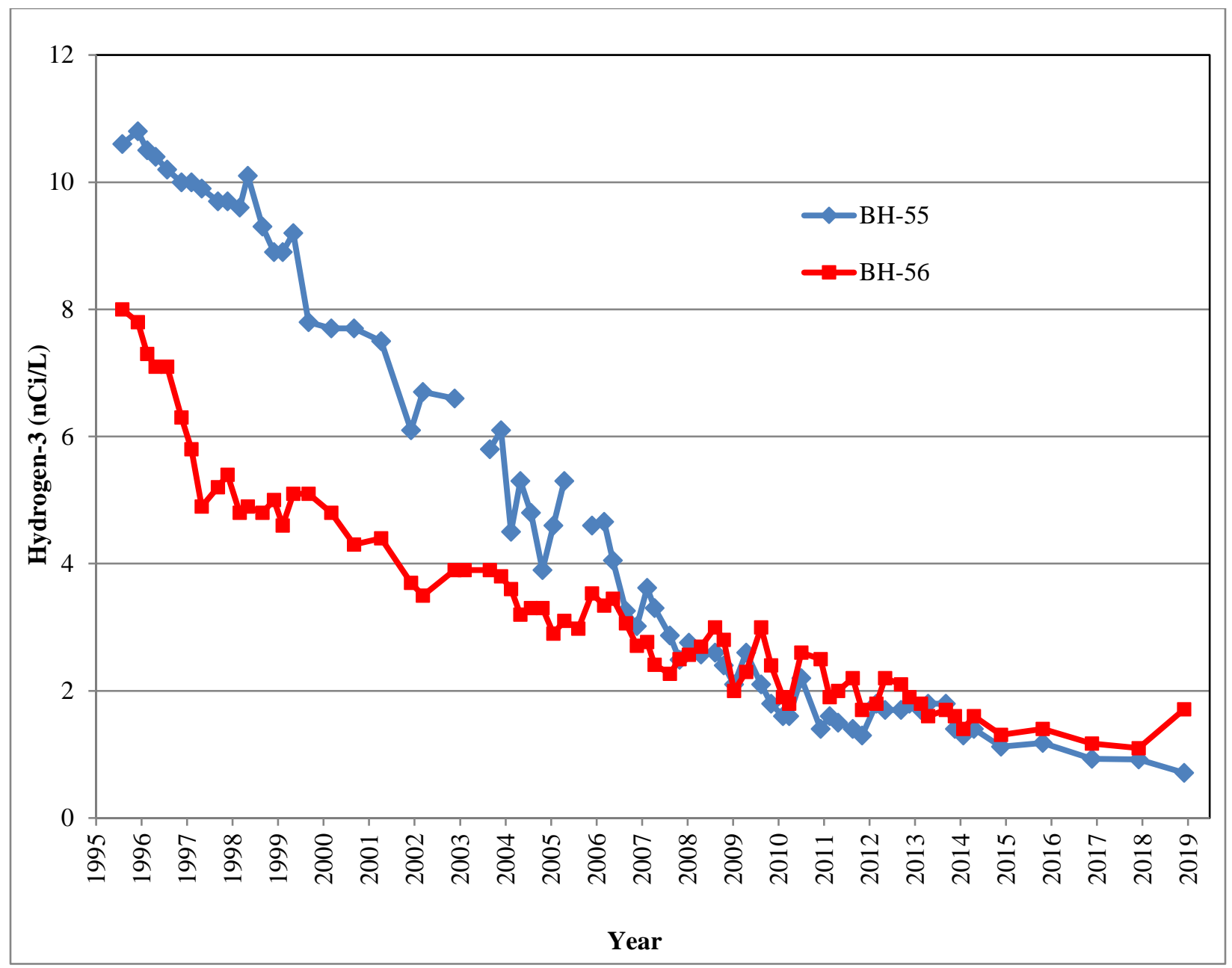

Figure 4.9 Hydrogen-3 in Site A Wells BH55 and BH56

Table 4.8 Water Level Measurements in Monitoring Wells Near Site A, 2019

\begin{tabular}{|c|c|c|c|c|}
\hline \multirow[b]{2}{*}{$\begin{array}{c}\text { Well } \\
\text { Number }\end{array}$} & \multirow[b]{2}{*}{$\begin{array}{l}\text { Depth to } \\
\text { Bottom } \\
\text { (ft.) }\end{array}$} & \multirow{2}{*}{$\begin{array}{c}\text { Top of } \\
\text { Casing } \\
\text { Elevation } \\
(\mathrm{ft} \text { AMSL) }\end{array}$} & \multicolumn{2}{|c|}{ June 19} \\
\hline & & & $\begin{array}{l}\text { Depth to water } \\
\text { (ft.) }\end{array}$ & $\begin{array}{l}\text { Water Surface } \\
\text { Elevation } \\
\text { (ft AMSL) }\end{array}$ \\
\hline $\mathrm{BH} 55$ & 87.2 & 743.78 & 65.20 & 678.58 \\
\hline $\mathrm{BH} 56$ & 102.4 & 742.23 & 85.10 & 657.13 \\
\hline
\end{tabular}

${ }^{1}$ From 1996 Advanced Surveying and Mapping topo map,

AMSL = Above mean sea level. 
During the last few years, this report has contained a map showing groundwater surface elevation contour lines and groundwater flow directions at Site A, based on groundwater elevation measurements. However, four of the wells that were used for this analysis were removed in 2015. The remaining two wells do not provide sufficient information to generate a groundwater elevation contour map. Thus, this information in not included in this report.

\section{$4.4 \quad$ Dolomite Well Water}

Six wells cased into the dolomite bedrock were sampled once in 2019 to monitor the movement of hydrogen-3 within this aquifer, located downgradient of Plot M. One of the dolomite wells is located near Plot M, and five are located north of Plot M in the Red Gate Woods area, as shown in Figure 4.10. All samples were analyzed for hydrogen-3. The results are shown in Table 4.9. All of the dolomite wells exhibited low but measurable hydrogen-3 concentrations, and all of the results are consistent with concentrations measured in the past. The well with the consistently highest hydrogen-3 results is DH15. Figure 4.11 shows the hydrogen-3 concentrations in $\mathrm{DH} 15$ since 1990 . The hydrogen-3 results have been relatively stable in this well since 1997 . All of the dolomite well samples were below the State of Illinois Class 1 Groundwater Quality Standard of $20 \mathrm{nCi} / \mathrm{L}$. The presence of hydrogen-3 in these wells is explained by the 1988 USGS investigation ${ }^{41}$, which indicated a hydrogen-3 plume underlies the stream which flows from Plot $M$ and passes to the northeast of these wells. The plume has spread downward and downgradient, resulting in small amounts of hydrogen-3 in the dolomite aquifer in this area.

Other dolomite wells, $\mathrm{DHO3}$ and $\mathrm{DH} 04$, are located close to and downgradient of Plot M. The 2018 hydrogen-3 result for $\mathrm{DH} 03$ was $5.07 \mathrm{nCi} / \mathrm{L}$, which is slightly higher than previous samples. The hydrogen-3 concentration in remaining dolomite wells were below $2.5 \mathrm{nCi} / \mathrm{L}$. Previous analyses of soil core samples ${ }^{42}$ indicated the presence of hydrogen- 3 as deep as the drift-dolomite interface in the vicinity of these wells. 


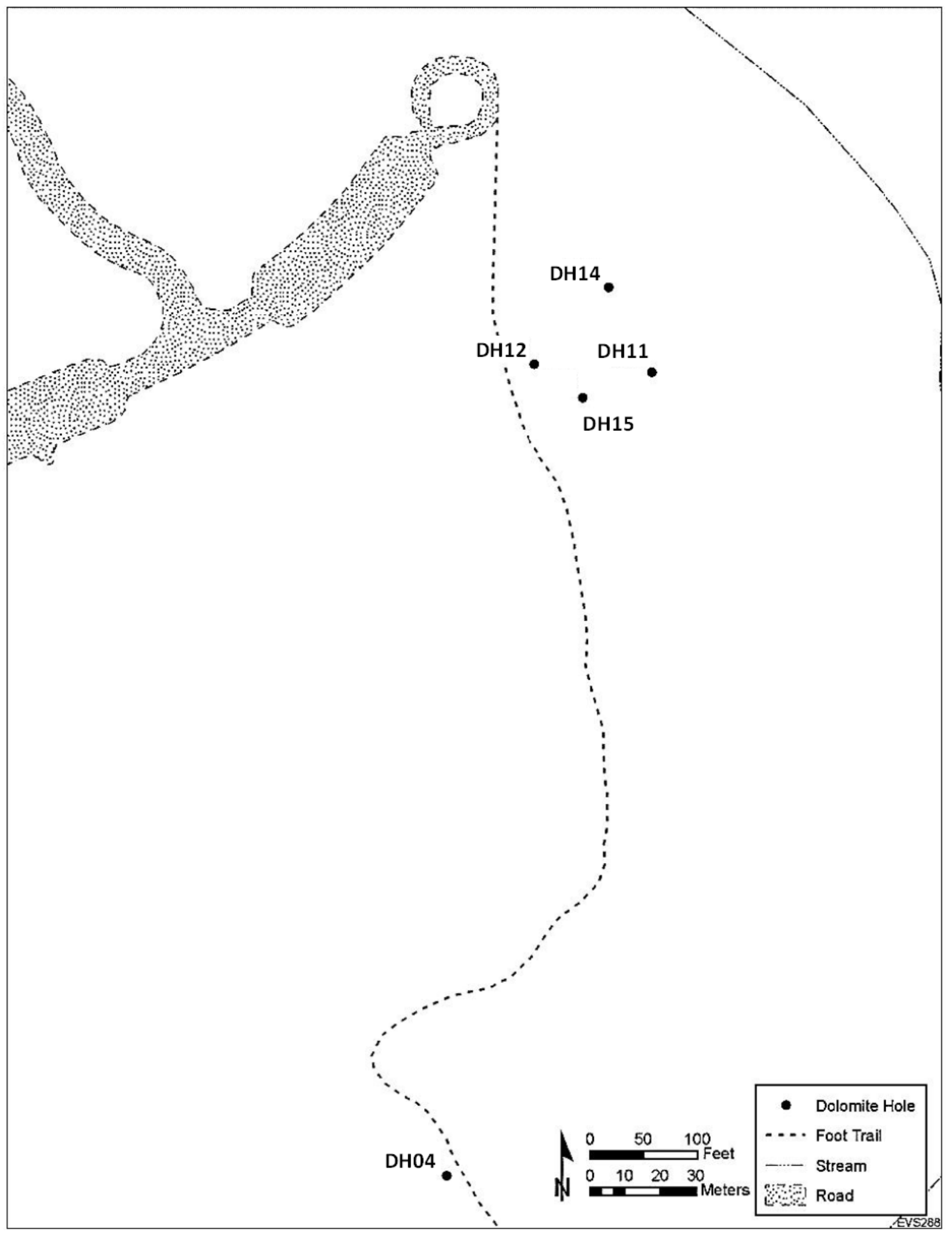

Figure 4.10 Locations of Dolomite Wells North of Plot M 
Table 4.9 Hydrogen-3 Content of Dolomite Well Water, 2019

\begin{tabular}{cc}
\hline $\begin{array}{c}\text { Dolomite } \\
\text { Well Number }\end{array}$ & $\begin{array}{c}\text { June } 20 \\
\text { (Concentrations in nCi/L) }\end{array}$ \\
\hline DH03 & $0.96(1.31)$ \\
DH04 & 1.18 \\
DH11 & 0.54 \\
DH12 & 0.48 \\
DH14 & 0.48 \\
DH15 & 2.31 \\
\hline
\end{tabular}

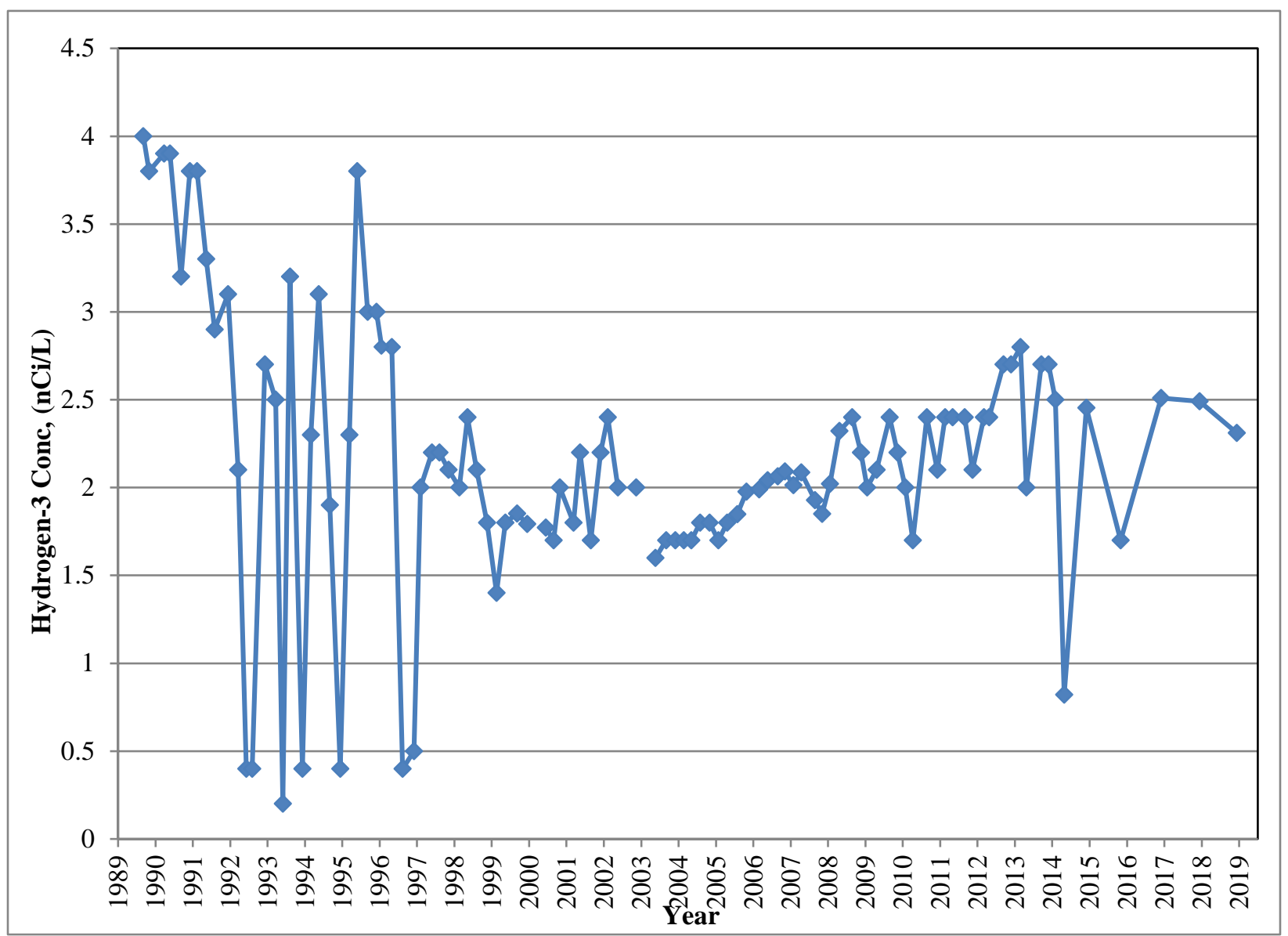

Figure 4.11 Hydrogen-3 Concentrations in Dolomite Well DH15 
Water levels were measured in the dolomite wells, as shown in Table 4.10. Since these wells are installed in the dolomite aquifer, which is much deeper and not affected as much by weather, the groundwater elevations showed a seasonal variation of lower magnitude than what was observed in the shallow glacial till wells. The groundwater elevations were consistent with historical measurements in these wells.

Since the remaining four wells in this area are located very close to one another, it is not possible to use groundwater elevation information to develop groundwater elevation contour maps. However, the relative elevation of the groundwater surface in the wells indicates that the groundwater is moving towards the nearby canal/river system, as described in the 1994 IT report ${ }^{42}$, which concluded that groundwater in this area is moving towards the Des Plaines River Valley.

\subsection{Former Picnic Wells}

Sampling was conducted once during 2019 at two disabled forest preserve picnic wells (\#5160 and \#5159) located north of Plot M, as shown in Figure 2.2. The Red Gate Woods North Well (\#5160) was disabled in 1999, due to high fecal coliform bacteria levels, by removing the pump handle. The well opposite Red Gate Woods (\#5159) is in an undeveloped area of the park and is unusable as a water source since the pump handle has also been removed. The samples were analyzed for hydrogen-3, with the results listed in Table 4.11. The maximum and average hydrogen-3 concentrations since 1996 for wells \#5160 and \#5159 are presented in Table 4.12. The change in hydrogen-3 concentrations in these wells since 1992 is shown in Figure 4.12.

The 2019 hydrogen-3 concentration in well \#5160 was similar to the concentrations observed since 2012. For unknown reasons, the hydrogen-3 levels in this well increased between 2010 and 2013, after experiencing a significant decrease in 2008. The 2019 sample collected from well \#5159 contained a concentration of hydrogen-3 similar to previous years. The concentrations of hydrogen-3 in these picnic wells are below the State of Illinois Primary Drinking Water Standard of $20 \mathrm{nCi} / \mathrm{L}$. 
Table 4.10 Water Level Measurements in Dolomite Wells, 2019

\begin{tabular}{|c|c|c|c|c|}
\hline \multirow[b]{2}{*}{$\begin{array}{c}\text { Well } \\
\text { Number }\end{array}$} & \multirow{2}{*}{$\begin{array}{l}\text { Ground } \\
\text { Surface } \\
\text { Elevation } \\
\text { (ft. AMSL) }\end{array}$} & \multirow{2}{*}{$\begin{array}{l}\text { Top of } \\
\text { Casing } \\
\text { Elevation } \\
\text { (ft. AMSL) }{ }^{1}\end{array}$} & \multicolumn{2}{|c|}{ June 20} \\
\hline & & & $\begin{array}{l}\text { Depth to water } \\
\text { (ft.) }\end{array}$ & $\begin{array}{c}\text { Water Surface Elevation } \\
\text { (ft. AMSL) }\end{array}$ \\
\hline $\mathrm{DHO3}$ & 678.10 & 679.50 & 95.47 & 584.03 \\
\hline $\mathrm{DH} 04$ & 673.80 & 674.60 & 91.10 & 583.50 \\
\hline DH11 & 655.36 & 656.90 & 73.40 & 581.96 \\
\hline $\mathrm{DH} 12$ & 650.34 & 651.60 & 74.49 & 575.85 \\
\hline $\mathrm{DH} 14$ & 651.43 & 653.20 & 69.50 & 581.93 \\
\hline DH15 & 659.14 & 660.80 & 77.15 & 581.99 \\
\hline
\end{tabular}

${ }^{1}$ From 1994 IT Study report. AMSL = Above mean sea level.

Table 4.11 Hydrogen-3 Content of Former Picnic Wells Near Site A/Plot M, 2019

\begin{tabular}{lc}
\hline \multicolumn{1}{c}{ Date Collected } & $\begin{array}{c}\text { June } 19 \\
\text { (Concentrations in nCi/L) }\end{array}$ \\
\hline Opposite Red Gate 5159 & 0.20 \\
Red Gate North 5160 & 0.80 \\
\hline
\end{tabular}


Table 4.12 Hydrogen-3 Concentrations in the Red Gate Woods Wells

\begin{tabular}{|c|c|c|c|c|}
\hline \multirow[b]{2}{*}{ Year } & \multicolumn{2}{|c|}{$\begin{array}{l}\text { Red Gate Woods North } \\
\qquad(\# 5160)\end{array}$} & \multicolumn{2}{|c|}{$\begin{array}{l}\text { Opposite Red Gate Woods } \\
\text { (\#5159) }\end{array}$} \\
\hline & $\begin{array}{l}\text { Maximum } \\
(\mathrm{nCi} / \mathrm{L})\end{array}$ & $\begin{array}{c}\text { Annual Average } \\
(\mathrm{nCi} / \mathrm{L})\end{array}$ & $\begin{array}{l}\text { Maximum } \\
(\mathrm{nCi} / \mathrm{L})\end{array}$ & $\begin{array}{c}\text { Annual Average } \\
(\mathrm{nCi} / \mathrm{L})\end{array}$ \\
\hline 1996 & 2.19 & 1.56 & 0.55 & 0.33 \\
\hline 1997 & 1.26 & 1.00 & 1.13 & 0.35 \\
\hline 1998 & 1.23 & 1.03 & 0.72 & 0.47 \\
\hline 1999 & 1.22 & 1.07 & 2.14 & 0.45 \\
\hline 2000 & 1.54 & 1.33 & 2.20 & 0.70 \\
\hline 2001 & 1.59 & 1.49 & 0.27 & 0.16 \\
\hline 2002 & 1.47 & 1.04 & 3.17 & 0.45 \\
\hline 2003 & 1.78 & 1.06 & 1.49 & 0.43 \\
\hline 2004 & 1.08 & 1.00 & 0.34 & 0.17 \\
\hline 2005 & 1.01 & 0.95 & 0.34 & 0.19 \\
\hline 2006 & 1.14 & 1.06 & 2.63 & 1.11 \\
\hline 2007 & 1.45 & 1.28 & 0.66 & 0.33 \\
\hline 2008 & 1.24 & 0.33 & 0.32 & 0.26 \\
\hline 2009 & 0.13 & 0.10 & 0.50 & 0.33 \\
\hline 2010 & 0.28 & 0.19 & 0.51 & 0.34 \\
\hline 2011 & 0.91 & 0.67 & 3.60 & 1.10 \\
\hline 2012 & 2.10 & 1.60 & 0.74 & 0.34 \\
\hline 2013 & 2.24 & 2.14 & 0.75 & 0.35 \\
\hline 2014 & 2.02 & 1.96 & 0.55 & 0.37 \\
\hline 2015 & 1.92 & $-^{a}$ & 0.51 & - \\
\hline 2016 & 1.71 & - & 1.16 & - \\
\hline 2017 & 1.28 & - & 0.70 & - \\
\hline 2018 & 1.33 & - & 0.48 & - \\
\hline 2019 & 0.80 & - & 0.20 & - \\
\hline
\end{tabular}

a An annual sampling frequency started in 2015. 


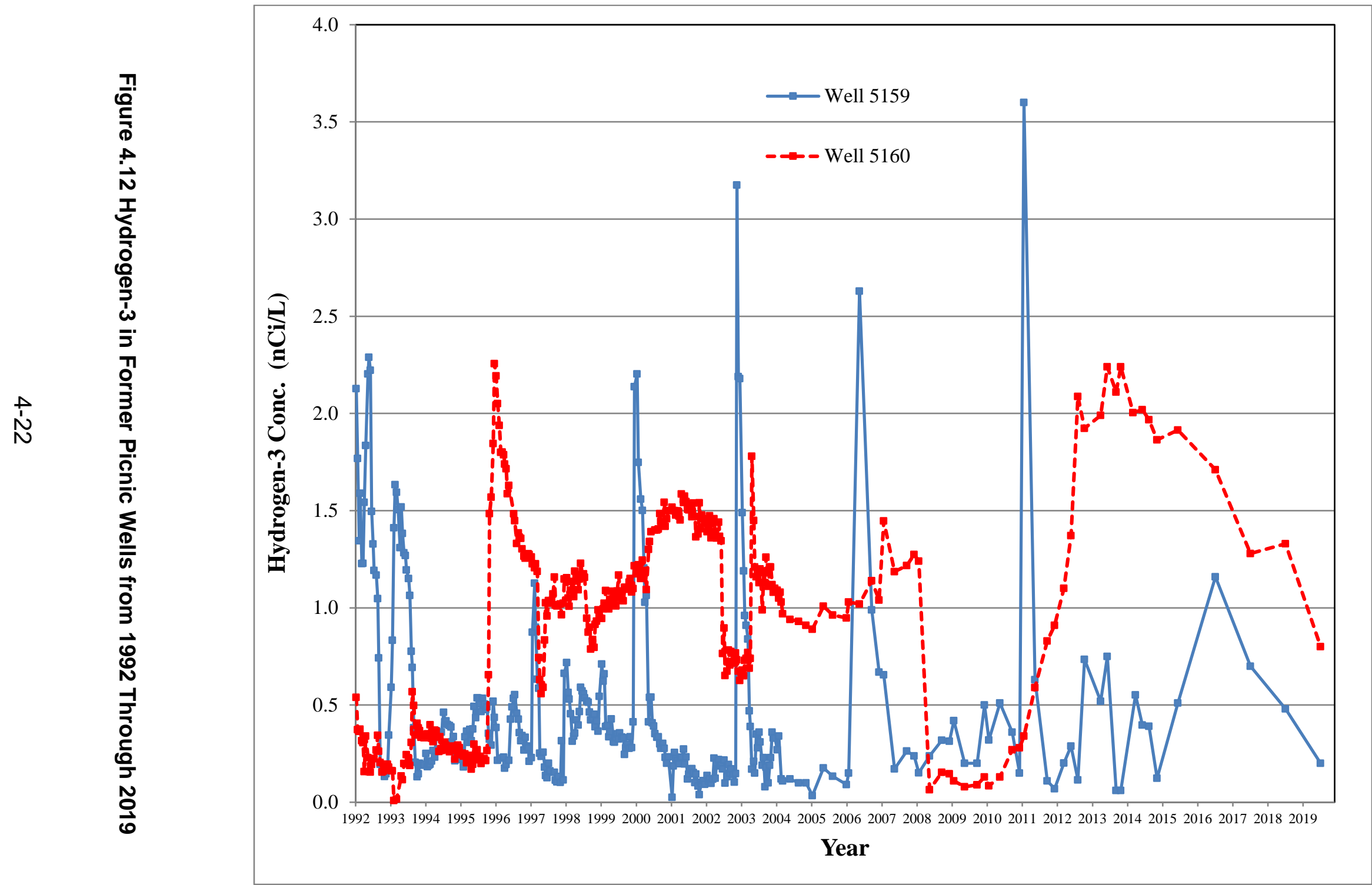




\subsection{SUMMARY OF POTENTIAL RADIATION DOSE AND RISK ESTIMATES}

\subsection{Dose Estimates}

Since there is no human consumption of water from surface water or wells, the radioactive material present in this area does not represent a health risk to the public. However, to evaluate the theoretical risk to health from residual contamination if this water were to be consumed by an individual, the potential radiation dose to a hypothetical individual was estimated using methodology prescribed in DOE Order $\mathrm{O} 458.1 .{ }^{43}$ The committed effective dose equivalent from consumption of water was estimated by calculating the total quantity of hydrogen-3 potentially ingested. Taking a very conservative approach, it was assumed the hypothetical individual drank only water containing hydrogen-3 at the maximum levels found at the Plot M (Stream Location 7) during 2019. The concentration of hydrogen-3 was multiplied by the general public water ingestion rate of $730 \mathrm{~L} / \mathrm{y} .{ }^{44}$ This annual intake was then multiplied by the 50 -year Committed Effective Dose Equivalent (CEDE) factor. ${ }^{45}$ The CEDE for hydrogen-3 in water is $7.2 \times 10^{-5} \mathrm{rem} / \mu \mathrm{Ci}$ (based on the derived concentration standard of $1.9 \times 10^{-3} \mu \mathrm{Ci} / \mathrm{mL}$ ). The worst case annual dose based on the maximum 2019 concentration of $30.1 \mathrm{nCi} / \mathrm{L}$ was determined to be $1.58 \mathrm{mrem} / \mathrm{y}$. A similar dose calculation was made for the former Red Gate Woods North Well (\#5160), assuming this was the sole source of water consumed. For this well, the estimated dose was $0.04 \mathrm{mrem} / \mathrm{y}$. For the Opposite Red Gate Woods Well (\#5159), the estimated dose was $0.01 \mathrm{mrem}$. These estimated doses are shown in Table 5.1. The DOE dose limit for the public is $100 \mathrm{mrem} / \mathrm{y}$, so even under a highly conservative scenario, the potential dose is far below DOE limits.

A more realistic estimation was made based upon the scenario of an occasional visitor to the Plot $\mathrm{M}$ area. The doses from this potential exposure were estimated by assuming a visitor drinks one liter of water from the surface stream and one liter of water from the Red Gate Woods North (\#5160) picnic well, and combining the two doses. The results are shown in Table 5.2. The maximum estimated dose was 0.0022 mrem per visit. In order to put the doses into perspective with other types of radiation exposure, comparisons can be made to annual average doses received by the public from natural or other generally accepted sources of radiation. ${ }^{46}$ These are listed in Table 5.3. It is obvious that the magnitude of the doses potentially received near Plot $\mathrm{M}$ from radioactive substances are insignificant compared to other common sources. 


\subsection{Risk Estimates}

The potential for possible negative health effects from radiation doses received from Plot M were estimated, to gain another perspective on interpreting the effects of radiation. Estimates for carcinogenic risk, the risk of contracting cancer from these exposures, are included in Table 5.1 and Table 5.2. Based on the BIER $V$ report, ${ }^{47}$ a dose of one mrem/y equates to an increased cancer risk of $7 \times 10^{-7}$. This conversion ratio is used to estimate incremental risk of contracting cancer from radiation exposure. For example, a carcinogenic risk of $10^{-7}$ would mean, on average, one additional cancer in 10,000,000 people exposed under the assumed exposure conditions. The EPA environmental protection standards are based upon an acceptable risk between $10^{-4}$ and $10^{-6}$. Table 5.1 indicates that under a very conservative assumption of ingestion of only Plot M surface water containing hydrogen-3 at the maximum concentration, the estimated risk is $1.1 \times 10^{-6}$, which is consistent with EPA standards. Table 5.2 shows that the hypothetical maximum dose of $0.0022 \mathrm{mrem} / \mathrm{y}$ to an occasional visitor would result in an increased cancer risk of about $1.5 \times 10^{-9}$. The incremental risk from exposure to radionuclides at Plot $\mathrm{M}$ can be compared to the risk associated with various life events. Examples are shown in Table 5.4. The risk from naturally occurring sources of radioactivity listed in Table 5.3 is estimated to be about one additional cancer in a population of 4,600. The incremental risk from residual contamination at Site A/Plot $\mathrm{M}$, under even the most conservative assumptions, is low. The monitoring program results have demonstrated that the impact of radioactivity at Site A/Plot $M$ is very low and does not endanger the health of those living in the area or visiting the site. 
Table 5.1 Hypothetical Dose from Exposure to Hydrogen-3, 2019

\begin{tabular}{|c|c|c|c|}
\hline \multirow[b]{2}{*}{ Assumed Source } & \multicolumn{2}{|c|}{ Maximum } & \multirow{2}{*}{$\begin{array}{c}\text { Maximum } \\
\text { Carcinogenic Risk }\end{array}$} \\
\hline & $\begin{array}{l}\text { Conc. } \\
\text { (nCi/L) }\end{array}$ & $\begin{array}{c}\text { Dose }^{1} \\
(\mathrm{mrem} / \mathrm{y})\end{array}$ & \\
\hline \multicolumn{4}{|l|}{ Surface Water } \\
\hline Plot M Location 7 & 30.1 & 1.58 & $1.1 \times 10^{-6}$ \\
\hline \multicolumn{4}{|l|}{$\underline{\text { Well Water }}$} \\
\hline $\begin{array}{l}\text { Red Gate Woods } \\
\text { North (\#5160) }\end{array}$ & 0.80 & 0.042 & $2.9 \times 10^{-8}$ \\
\hline $\begin{array}{l}\text { Opposite Red Gate Woods } \\
\text { (\#5159) }\end{array}$ & 0.20 & 0.011 & $0.73 \times 10^{-8}$ \\
\hline
\end{tabular}

${ }^{1}$ DOE Dose limit is $100 \mathrm{mrem} / \mathrm{year}$

Table 5.2 Hypothetical Dose Hydrogen-3 Exposures to a Casual Visitor, 2019

\begin{tabular}{lcc}
\hline \multicolumn{1}{c}{ Pathway } & $\begin{array}{c}\text { Maximum Dose } \\
\text { (mrem/visit) }\end{array}$ & $\begin{array}{c}\text { Maximum } \\
\text { Carcinogenic Risk }\end{array}$ \\
\hline$\underline{\text { Surface Water }}$ & 0.0022 & $1.5 \times 10^{-9}$ \\
Plot M Location 7 & & \\
Well Water & 0.00006 & $4.0 \times 10^{-11}$ \\
$\begin{array}{l}\text { Red Gate Woods } \\
\text { North (\#5160) }\end{array}$ & $1.54 \times 10^{-9}$ \\
Total & 0.00226 & \\
\hline${ }^{1}$ DOE Dose limit is $100 \mathrm{mrem} / \mathrm{year}$ & &
\end{tabular}


Table 5.3 Annual Average Dose Equivalent in the U. S. Population

\begin{tabular}{|c|c|}
\hline Sources $^{1}$ & Dose (mrem) \\
\hline \multicolumn{2}{|l|}{ Natural Sources } \\
\hline Radon & 228 \\
\hline Internal $\left({ }^{40} \mathrm{~K}\right.$ and $\left.{ }^{226} \mathrm{Ra}\right)$ & 29 \\
\hline Cosmic & 33 \\
\hline Terrestrial & 21 \\
\hline \multicolumn{2}{|l|}{ Medical } \\
\hline Computed Tomography & 147 \\
\hline Nuclear Medicine & 77 \\
\hline Interventional Fluoroscopy & 43 \\
\hline Conventional Radiography \& Fluoroscopy & 33 \\
\hline Consumer (All Sources) & 13 \\
\hline \multicolumn{2}{|l|}{ Building Materials } \\
\hline \multicolumn{2}{|l|}{ Commercial Air Travel } \\
\hline \multicolumn{2}{|l|}{ Cigarette Smoking } \\
\hline \multicolumn{2}{|l|}{ Mining and Agricultural } \\
\hline \multicolumn{2}{|l|}{ Combustion of Fossil Fuels } \\
\hline \multicolumn{2}{|l|}{ Highway and Road Construction Materials } \\
\hline \multicolumn{2}{|l|}{ Glass and Ceramics } \\
\hline Industrial (All Sources) & 0.3 \\
\hline \multicolumn{2}{|l|}{ Nuclear-power Generation } \\
\hline \multicolumn{2}{|l|}{ DOE Installations } \\
\hline \multicolumn{2}{|l|}{ Decommissioning and Radioactive Waste } \\
\hline \multicolumn{2}{|l|}{ Industrial, Medical, Educational, and Research Activities } \\
\hline \multicolumn{2}{|l|}{ Contact with Nuclear-medicine Patients } \\
\hline \multicolumn{2}{|l|}{ Security Inspection Systems } \\
\hline Occupational (All Sources) & 0.5 \\
\hline \multicolumn{2}{|l|}{ Medical } \\
\hline \multicolumn{2}{|l|}{ Aviation } \\
\hline \multicolumn{2}{|l|}{ Commercial Nuclear Power } \\
\hline \multicolumn{2}{|l|}{ Industrial and Commercial } \\
\hline \multicolumn{2}{|l|}{ Education and Research } \\
\hline \multicolumn{2}{|l|}{ Government, DOE, and Military } \\
\hline Total & 624 \\
\hline
\end{tabular}

${ }^{1} \mathrm{NCRP}$ report No. $160 .{ }^{48}$ 
Table 5.4 Annual Risk of Death from Various Events

\begin{tabular}{lc}
\hline \multicolumn{1}{c}{ Cause } & Risk \\
\hline Bee/wasp sting & $3.8 \times 10^{-8}$ \\
Lightning strike & $9.5 \times 10^{-8}$ \\
Storm & $4.4 \times 10^{-7}$ \\
Firearms & $2 \times 10^{-6}$ \\
Cycling & $2.9 \times 10^{-6}$ \\
Flood & $3.8 \times 10^{-6}$ \\
Fire & $9.6 \times 10^{-6}$ \\
Walking & $1.8 \times 10^{-5}$ \\
\hline
\end{tabular}

Source: The Economist, February 14, 2013 
This page intentionally left blank 


\subsection{QUALITY ASSURANCE PROGRAM}

The radiological instrumentation used in this program is calibrated with standardized sources obtained from or traceable to the U. S. National Institute of Standards and Technology (NIST). Calibration of the instrumentation is verified by using secondary counting standards prior to the analysis of the samples. Approximately $10 \%$ of the samples are analyzed in duplicate or with the addition of known amounts of a radionuclide to check precision and accuracy.

Argonne participates in the DOE Mixed-Analyte Performance Evaluation Program (MAPEP). The MAPEP is administered by the DOE Radiological and Environmental Sciences Laboratory (RESL), located in Idaho Falls, Idaho. RESL provides an unbiased technical component to DOE oversight of contractor operations at DOE facilities and sites. RESL conducts cost-effective measurement quality assurance programs that help assure that key DOE missions are completed in a safe and environmentally responsible manner. By assuring the quality and stability of key laboratory measurement systems throughout DOE, and by providing expert technical assistance to improve those systems and programs, it assures the reliability of data on which decisions are based. The primary objective of this performance evaluation program is to foster reliability and credibility for the analytical results used in the decision-making process, particularly as it relates to the environment and public health and safety. MAPEP checks for specific analytical proficiencies in radiological, stable inorganic, or organic analyses. The MAPEP study addresses data quality requirements in DOE Order 458.1, Radiation Protection of the Public and the Environment.

MAPEP studies are conducted each February and August. MAPEP samples include water, soil, and air filter matrices that are spiked with environmentally important stable inorganic, organic, and radioactive constituents that are traceable to the National Institute of Standards and Technology. RESL performs sample preparation, distribution, data evaluation, and reporting. The results of Argonne's participation in this program for 2018 are published in ANL-19/02. ${ }^{53}$

Many factors enter into an overall quality assurance program other than the analytical laboratory quality control process discussed above. Representative sampling is of prime importance. Appropriate sampling protocols are followed for each type of sample being collected. Water samples are pre-treated in a manner designed to maintain the integrity of the constituent of interest. For example, samples collected for strontium-90 analysis are filtered and acidified 
immediately after collection to prevent hydrolytic loss of metal ions and reduce leaching from suspended solids. Samples collected for hydrogen-3 analysis do not require filtration or acidification.

To ensure groundwater samples are representative of the in-place groundwater, stagnant water in the well is removed prior to sampling in accordance with EPA guidance ${ }^{50}$. The volume of stagnant water in the casing is determined by measuring the water depth from the surface. From one to three times the well volume is removed. After the well refills with groundwater, it is sampled by bailing with a Teflon bailer or dedicated pump. Wells that do not recharge quickly are pumped nearly dry and allowed to refill before samples are collected. The Red Gate Woods dolomite wells are not purged since they are open boreholes drilled into the bedrock where stagnant water does not accumulate. All samples are placed in precleaned bottles, labeled, filtered, and preserved (strontium-90 samples only). All sampling equipment is cleaned by field rinsing with Type II deionized water. The samples are transferred to the analytical laboratory, accompanied by a chain-of-custody transfer document.

\subsection{Applicable Standards}

The standard relevant to this study is the DOE Order O 458.1, "Radiation Protection of the Public and the Environment", which established a total effective dose limit of $100 \mathrm{mrem} / \mathrm{y} .{ }^{43}$ The dose limit and dose calculation methodology are applicable to all media: surface water, deep

holes, boreholes, and picnic well water. The EPA drinking water standard ${ }^{44}$ is not applicable to the picnic wells since they do not meet the definition of a public water system; however, the IEPA standard of $20 \mathrm{nCi} / \mathrm{L}$ for hydrogen-3 and the IEPA Class I groundwater standard of $8 \mathrm{pCi} / \mathrm{L}$ for strontium-90 are used in this report for comparison purposes.

\subsection{Analytical Methods}

The analytical methods used to obtain the data in this report are identical to those used to generate the results presented in ANL-19/02. ${ }^{53}$ 


\subsection{Intercomparison Program}

Commencing in 2012, Argonne has participated in a program of dividing a subset of the Site A/Plot $M$ water samples collected and submitting one half of each sample to the Illinois Emergency Management Agency (IEMA) for analysis. The IEMA operates a laboratory which conducts radiological analyses using methods similar to Argonne. A duplicate set of two samples during the first, third and fourth quarter and six samples during the second quarter is analyzed by both Argonne and the IEMA for hydrogen-3, strontium-90, and cesium-137. The results are compared to identify any discrepancies that may be occurring within the processes being conducted by the two analytical laboratories that would affect the results. The results from the 2019 split samples are shown in Tables 6.1 through 6.3. The relative percent difference (RPD) for hydrogen-3 results from pairs of samples exhibiting results greater than three times the minimum detectable activity (MDA) are shown in Tables 6.1. One strontium-90 result by Argonne exceeded three times the MDA level, but the IEMA result for that sample was below three times the MDA level. No other pairs of strontium-90 or cesium-137 results exceeded three times the MDA levels, thus the RPD was not calculated. 2019 Analytical Data analyzed by IEMA is shown in Appendix A. 
Table 6.1 Intercomparison Sample Hydrogen-3 Results for 2019

\begin{tabular}{|c|c|c|c|c|c|c|c|}
\hline Sampling Location & $\begin{array}{c}\text { Argonne } \\
\text { H-3 } \\
\text { Results } \\
\text { (nCi/L) } \\
\end{array}$ & $\begin{array}{l}\text { Argonne } \\
\text { Uncertainty }\end{array}$ & $\begin{array}{c}\text { Argonne } \\
\text { MDA }\end{array}$ & $\begin{array}{l}\text { IEMA H-3 } \\
\text { Results } \\
\text { (nCi/L) }\end{array}$ & $\begin{array}{c}\text { IEMA } \\
\text { Uncertainly }\end{array}$ & $\begin{array}{l}\text { IEMA } \\
\text { MDA }\end{array}$ & RPD $^{b}$ \\
\hline \multicolumn{8}{|l|}{ First Quarter } \\
\hline Plot M Borehole BH04 & $306^{a}$ & 0.717 & 0.1 & 308 & NA & 0.20 & $0.6 \%$ \\
\hline Plot M Borehole BH10 & 12.0 & 0.147 & 0.1 & 7.5 & NA & 0.20 & $46.1 \%$ \\
\hline \multicolumn{8}{|l|}{ Second Quarter } \\
\hline Plot M Borehole BH04 & 296 & 0.713 & 0.1 & 302 & NA & 0.20 & $2.0 \%$ \\
\hline Plot M Borehole BH10 & 12.5 & 0.153 & 0.1 & 13.5 & NA & 0.20 & $7.7 \%$ \\
\hline Site A Borehole BH56 & 1.71 & 0.067 & 0.1 & 0.96 & NA & 0.20 & $56.1 \%$ \\
\hline Picnic Well 5160 & 0.80 & 0.056 & 0.1 & 1.07 & NA & 0.20 & $28.8 \%$ \\
\hline RGW Dolomite Well DH11 & 0.54 & 0.049 & 0.1 & 0.51 & NA & 0.20 & $5.7 \%$ \\
\hline RGW Dolomite Well DH12 & 0.48 & 0.048 & 0.1 & 0.44 & NA & 0.20 & $8.7 \%$ \\
\hline \multicolumn{8}{|l|}{ Third Quarter } \\
\hline Plot M Borehole BH04 & 296 & 0.699 & 0.1 & 297 & NA & 0.20 & $0.3 \%$ \\
\hline Plot M Borehole BH10 & 29.4 & 0.228 & 0.1 & 33.5 & NA & 0.20 & $13.0 \%$ \\
\hline \multicolumn{8}{|l|}{ Fourth Quarter } \\
\hline Plot M Borehole BH04 & 304 & 0.729 & 0.1 & 303 & NA & 0.20 & $0.3 \%$ \\
\hline Plot M Borehole BH10 & 12.8 & 0.155 & 0.1 & 14.0 & NA & 0.20 & $8.9 \%$ \\
\hline
\end{tabular}

a Bold font indicates the result is greater than three times the MDA

b Relative Percent Difference (RPD) was calculated only for those results where both Argonne and IEMA results were greater than three times the MDA 
Table 6.2 Intercomparison Sample Strontium-90 Results for 2019

\begin{tabular}{|c|c|c|c|c|c|c|}
\hline Sampling Location & $\begin{array}{c}\text { Argonne } \\
\text { Sr-90 } \\
\text { Results } \\
\text { (pCi/L) }\end{array}$ & $\begin{array}{l}\text { Argonne } \\
\text { Uncertainty }\end{array}$ & $\begin{array}{l}\text { Argonne } \\
\text { MDA }\end{array}$ & $\begin{array}{c}\text { IEMA } \\
\text { Sr-90 } \\
\text { Results } \\
\text { (pCi/L) }\end{array}$ & $\begin{array}{c}\text { IEMA } \\
\text { Uncertainly }\end{array}$ & $\begin{array}{l}\text { IEMA } \\
\text { MDA }\end{array}$ \\
\hline \multicolumn{7}{|l|}{ First Quarter } \\
\hline Plot M Borehole \#4 & -0.001 & 0.0214 & 0.25 & $<0.9$ & NA & 1.1 \\
\hline Plot M Borehole \#10 & 0.179 & 0.0281 & 0.25 & $<0.9$ & NA & 1.1 \\
\hline \multicolumn{7}{|l|}{ Second Quarter } \\
\hline Plot M Borehole \#4 & -0.0201 & 0.0203 & 0.25 & $<0.9$ & NA & 1.1 \\
\hline Plot M Borehole \#10 & 0.187 & 0.0259 & 0.25 & $<0.9$ & NA & 1.1 \\
\hline Site A Borehole \#56 & $0.930^{\mathrm{a}}$ & 0.0850 & 0.25 & 1.8 & NA & 1.1 \\
\hline Picnic Well 5160 & -0.0277 & 0.0187 & 0.25 & $<0.9$ & NA & 1.1 \\
\hline RGW Dolomite Well \#11 & -0.021 & 0.0178 & 0.25 & $<0.9$ & NA & 1.1 \\
\hline RGW Dolomite Well \#12 & -0.008 & 0.0184 & 0.25 & $<0.9$ & NA & 1.1 \\
\hline \multicolumn{7}{|l|}{ Third Quarter } \\
\hline Plot M Borehole \#4 & 0.0513 & 0.0226 & 0.25 & $<0.9$ & NA & 1.1 \\
\hline Plot M Borehole \#10 & 0.2624 & 0.0328 & 0.25 & $<0.9$ & NA & 1.1 \\
\hline \multicolumn{7}{|l|}{ Fourth Quarter } \\
\hline Plot M Borehole \#4 & -0.0018 & 0.0237 & 0.25 & $<0.9$ & NA & 1.1 \\
\hline Plot M Borehole \#10 & 0.2003 & 0.0282 & 0.25 & $<0.9$ & NA & 1.1 \\
\hline
\end{tabular}


Table 6.3 Intercomparison Sample Cesium-137 Results for 2019

\begin{tabular}{|c|c|c|c|c|c|c|}
\hline Sampling Location & $\begin{array}{c}\text { Argonne } \\
\text { Cs-137 } \\
\text { Results } \\
\text { (pCi/L) }\end{array}$ & $\begin{array}{l}\text { Argonne } \\
\text { Uncertainty }\end{array}$ & $\begin{array}{l}\text { Argonne } \\
\text { MDA }\end{array}$ & $\begin{array}{c}\text { IEMA } \\
\text { Cs-137 } \\
\text { Results } \\
\text { (pCi/L) } \\
\end{array}$ & $\begin{array}{c}\text { IEMA } \\
\text { Uncertainly }\end{array}$ & $\begin{array}{l}\text { IEMA } \\
\text { MDA }\end{array}$ \\
\hline \multicolumn{7}{|l|}{ First Quarter } \\
\hline Plot M Borehole \#4 & 0.343 & 1.91 & 2 & $<4.0$ & NA & $<4.0$ \\
\hline Plot M Borehole \#10 & 1.17 & 1.43 & 2 & $<4.0$ & NA & $<4.0$ \\
\hline \multicolumn{7}{|l|}{ Second Quarter } \\
\hline Plot M Borehole \#4 & 0.137 & 1.85 & 2 & $<4.0$ & NA & $<4.0$ \\
\hline Plot M Borehole \#10 & -0.017 & 1.93 & 2 & $<4.0$ & NA & $<4.0$ \\
\hline Site A Borehole \#56 & -1.543 & 1.90 & 2 & $<4.0$ & NA & $<4.0$ \\
\hline Picnic Well 5160 & -0.925 & 1.91 & 2 & $<4.0$ & NA & $<4.0$ \\
\hline RGW Dolomite Well \#11 & -0.037 & 1.86 & 2 & $<4.0$ & NA & $<4.0$ \\
\hline RGW Dolomite Well \#12 & -1.955 & 1.85 & 2 & $<4.0$ & NA & $<4.0$ \\
\hline \multicolumn{7}{|l|}{ Third Quarter } \\
\hline Plot M Borehole \#4 & 0.0343 & 1.895 & 2 & $<4.0$ & NA & $<4.0$ \\
\hline Plot M Borehole \#10 & 0.7551 & 1.872 & 2 & $<4.0$ & NA & $<4.0$ \\
\hline \multicolumn{7}{|l|}{ Fourth Quarter } \\
\hline Plot M Borehole \#4 & -0.7191 & 1.89 & 2 & $<4.0$ & NA & $<4.0$ \\
\hline Plot M Borehole \#10 & 0.1028 & 1.86 & 2 & $<4.0$ & NA & $<4.0$ \\
\hline
\end{tabular}




\subsection{REFERENCES}

1. Golchert, N. W. and Sedlet, J., Formerly Utilized MED/AEC Sites Remedial Action Program - Radiological Survey of Site A, Palos Park Forest Preserve, Chicago, Illinois, U. S. Department of Energy Report DOE/EV-0005/7 (April 1978).

2. Golchert, N. W., Sedlet, J., and Hayes, K. A., Environmental Surveillance of the Palos Park Forest Preserve, Argonne National Laboratory Report ANL-83-6 (January 1983).

3. Golchert, N. W. and Sedlet, J., Site Surveillance and Maintenance Program for Palos Park - Report for 1982, Argonne National Laboratory (available from the authors) (April 1984).

4. Golchert, N. W. and Sedlet, J., Site Surveillance and Maintenance Program for Palos Park - Report for 1983, Argonne National Laboratory (available from the authors) (June 1984).

5. Golchert, N. W. and Sedlet, J., Site Surveillance and Maintenance Program for Palos Park - Report for 1984, Argonne National Laboratory (available from the authors) (April 1985).

6. Golchert, N. W. and Sedlet, J., Site Surveillance and Maintenance Program for Palos Park - Report for 1985, Argonne National Laboratory Report ANL-86-25 (April 1986).

7. Golchert, N. W., Site Surveillance and Maintenance Program for Palos Park - Report for 1986, Argonne National Laboratory Report ANL-87-8 (April 1987).

8. Golchert, N. W., Site Surveillance and Maintenance Program for Palos Park - Report for 1987, Argonne National Laboratory Report ANL-88-12 (April 1988).

9. Golchert, N. W., Site Surveillance and Maintenance Program for Palos Park - Report for 1988, Argonne National Laboratory Report ANL-89/7 (April 1989).

10. Golchert, N. W., Surveillance of Site A and Plot M - Report for 1989, Argonne National Laboratory Report ANL-90/7 (April 1990).

11. Golchert, N. W., Surveillance of Site A and Plot M - Report for 1990, Argonne National Laboratory Report ANL-91/2 (May 1991).

12. Golchert, N. W., Surveillance of Site A and Plot M - Report for 1991, Argonne National Laboratory Report ANL-92/13 (May 1992).

13. Golchert, N. W., Surveillance of Site A and Plot M - Report for 1992, Argonne National Laboratory Report ANL-93/4 (May 1993).

14. Golchert, N. W., Surveillance of Site A and Plot M - Report for 1993, Argonne National Laboratory Report ANL-94/9 (May 1994).

15. Golchert, N. W., Surveillance of Site A and Plot M - Report for 1994, Argonne National Laboratory Report ANL-95/7 (May 1995). 
16. Golchert, N. W., Surveillance of Site A and Plot M - Report for 1995, Argonne National Laboratory Report ANL-96/2 (June 1996).

17. Golchert, N. W., Surveillance of Site A and Plot M - Report for 1996, Argonne National Laboratory Report ANL-97/5 (May 1997).

18. Golchert, N. W., Surveillance of Site A and Plot M - Report for 1997, Argonne National Laboratory Report ANL-98/1 (May 1998).

19. Golchert, N. W., Surveillance of Site A and Plot M - Report for 1998, Argonne National Laboratory Report ANL-99/2 (May 1999).

20. Golchert, N. W., Surveillance of Site A and Plot M - Report for 1999, Argonne National Laboratory Report ANL-00/3 (May 2000).

21. Golchert, N. W., Surveillance of Site A and Plot M - Report for 2000, Argonne National Laboratory Report ANL-01/1 (May 2001).

22. Golchert, N. W., Surveillance of Site A and Plot M - Report for 2001, Argonne National Laboratory Report ANL-02/1 (May 2002).

23. Golchert, N. W., Surveillance of Site A and Plot M - Report for 2002, Argonne National Laboratory Report ANL-03/1 (May 2003).

24. Golchert, N. W., Surveillance of Site A and Plot M - Report for 2003, Argonne National Laboratory Report ANL-04/1 (May 2004).

25. Golchert, N. W., Surveillance of Site A and Plot M - Report for 2004, Argonne National Laboratory Report ANL-05/01 (April 2005).

26. Golchert, N. W., Surveillance of Site A and Plot M - Report for 2005, Argonne National Laboratory Report ANL-06/01 (April 2006).

27. Golchert, N. W., Surveillance of Site A and Plot M - Report for 2006, Argonne National Laboratory Report ANL-07/01 (April 2007).

28. Golchert, N. W., Surveillance of Site A and Plot M - Report for 2007, Argonne National Laboratory Report ANL-08/04 (March 2008).

29. Golchert, N. W., Surveillance of Site A and Plot M - Report for 2008, Argonne National Laboratory Report ANL-09/01 (April 2009).

30. Golchert, N. W., Surveillance of Site A and Plot M - Report for 2009, Argonne National Laboratory Report ANL-10/01 (April 2010).

31. Golchert, N. W., Surveillance of Site A and Plot M - Report for 2010, Argonne National Laboratory Report ANL-11/01 (May 2011). 
32. Golchert, N. W. and Moos, L.P., Surveillance of Site A and Plot M - Report for 2011, Argonne National Laboratory Report ANL-12/01 (June 2012).

33. Moos, L.P., Surveillance of Site A and Plot M - Report for 2012, Argonne National Laboratory Report ANL-13/01 (June 2013).

34. Moos, L.P., Surveillance of Site A and Plot M - Report for 2013, Argonne National Laboratory Report ANL-14/01 (June 2014).

35. Moos, L.P., Surveillance of Site A and Plot M - Report for 2014, Argonne National Laboratory Report ANL-15/01 (June 2015).

36. Moos, L.P., Surveillance of Site A and Plot M - Report for 2015, Argonne National Laboratory Report ANL-16/01 (June 2016).

37. U. S. Department of Energy Office of Legacy Management, "Long-Term Surveillance and Maintenance Plan for Site A and Plot M, Palos Forest Preserve, Cook County, Illinois", LMS/SAM/S01063-1.0, January, 2015

38. U. S. Department of Energy Office of Legacy Management, "Groundwater and Surface Water Monitoring Activities at Site A and Plot M", LMS/SAM/S07581, March 2011.

39. U. S. Department of Energy Office of Legacy Management, "Supplemental Assessment: Groundwater and Surface Water Monitoring Activities at Site A and Plot M", 2014.

40. U. S. Department of Energy, "Environmental Regulatory Guide for Radiological Effluent Monitoring and Environmental Surveillance," DOE/EH-0173T, January 1991.

41. Nicholas, J. R. and Healy, R. W., "Hydrogen-3 Migration from a Low-Level RadioactiveWaste Disposal Site Near Chicago, Illinois," U. S. Geological Survey Water-Supply Paper 2333, 1988.

42. International Technology Corporation, "Tritium Migration and Hydrogeological Studies in the Vicinity of Plot M Palos Forest Preserve", August, 1994.

43. U. S. Department of Energy, "Radiation Protection of the Public and the Environment," DOE O 458.1, Change 2, June 6, 2011.

44. U. S. Environmental Protection Agency, "National Primary Drinking Water Regulations," 40 CFR Part 141.

45. U. S. Department of Energy, "Derived Concentration Technical Standard," DOE-STD1196-2011, April 2011.

46. International Commission on Radiological Protection, "Reference Man: Anatomical, Physiological, and Metabolic Characteristics," ICRP Publication 23, Pergamon Press, New York, NY (1975). 
47. Committee on Biological Effects of Ionizing Radiation, Health Effects on Populations of Exposure to Low Levels of Ionizing Radiation - BEIR V Report, National Academy Press, Washington, 1990.

48. National Council on Radiation Protection and Measurements, Ionizing Radiation Exposure of the Population of the United States, NCRP Report No. 160, August 20, 2009.

49. Davis, T.M., J.L. Gomez, Moos, L.P, Argonne National Laboratory Site Environmental Report for Calendar Year 2014, Argonne National Laboratory Report, ANL-15/02 (September 2015).

50. U. S. Environmental Protection Agency, 1986, RCRA Ground Water Monitoring Technical Enforcement Guidance Document, OSWER-9950.1, Office of Solid Waste and Emergency Response, Washington, DC.

51. Davis, T.M., J.L. Gomez, Argonne National Laboratory Site Environmental Report for Calendar Year 2016, Argonne National Laboratory Report, ANL-17/02 (September 2017)

52. Davis, T.M., J.L. Gomez, Argonne National Laboratory Site Environmental Report for Calendar Year 2017, Argonne National Laboratory Report, ANL-18/01 (September 2018).

53. T.M. Davis, M.B. Mesarch, S.F. Miller, and C.M. Tucker, Argonne National Laboratory Site Environmental Report for Calendar Year 2018, Argonne National Laboratory Report, ANL-19/02 (September 2019).

54. Piorkowski, R.E., Surveillance of Site A and Plot M - Report for 2016, Argonne National Laboratory Report ANL-17/01 (August 2017).

55. Piorkowski, R.E., Surveillance of Site A and Plot M - Report for 2017, Argonne National Laboratory Report ANL-18/01 (June 2018).

56. Piorkowski, R.E., Surveillance of Site A and Plot M - Report for 2018, Argonne National Laboratory Report ANL-19/01 (August 2019). 


\subsection{DISTRIBUTION FOR ANL-20/01}

$\underline{\text { Internal }}$

G. Baudino

T. Davis

E. Dunn

J. Gomez

L. Krohn

W. Luck

D. McCormick

M. Mesarch

S. Miller

R. Piorkowski

T. Schneider

J. Tucker

Argonne Research Library

\section{External}

J. Barnette, U. S. Environmental Protection Agency, Region V

J. Carpino, Mayor of Willow Springs

N. Golchert

M. Hart, Forest Preserved District of Cook County

K. Horn, Illinois Emergency Management Agency

T. Hyde, U. S. Environmental Protection Agency

K. Joshi, DOE Argonne Site Office

A. Khayyat, Illinois Emergency Management Agency

J. Murl, DOE Grand Junction Office (2)

R. Pitchford, Illinois Emergency Management Agency

D. Robbins, Illinois Emergency Management Agency

T. Varchmin, Cook County Department of Public Health 


\section{APPENDIX A- 2019 IEMA ANALYTICAL DATA FOR SITE A /PLOT M}

\section{Table A.1 Tritium (H-3) Results for Water Samples Collected by Argonne and analyzed by IEMA Results are in picocuries per liter (pCi/L)}

\begin{tabular}{|c|c|c|}
\hline \multirow{2}{*}{$\begin{array}{l}\text { Location } \\
\text { Date }\end{array}$} & \multicolumn{2}{|c|}{$\mathrm{H}-3$} \\
\hline & Result & MDC \\
\hline \multicolumn{3}{|c|}{ Plot M Borehole \#10 } \\
\hline $3 / 27 / 2019$ & 7500 & 200 \\
\hline $6 / 19 / 2019$ & 13500 & 200 \\
\hline $9 / 18 / 2019$ & 33500 & 200 \\
\hline $12 / 12 / 2019$ & 14000 & 200 \\
\hline \multicolumn{3}{|c|}{ Plot M Borehole \#4 } \\
\hline $3 / 27 / 2019$ & 308000 & 200 \\
\hline $6 / 19 / 2019$ & 302000 & 200 \\
\hline $9 / 18 / 2019$ & 297000 & 200 \\
\hline $12 / 12 / 2019$ & 303000 & 200 \\
\hline \multicolumn{3}{|c|}{ Red Gate Woods Well \#5160 } \\
\hline $6 / 18 / 2019$ & 1030 & 200 \\
\hline \multicolumn{3}{|c|}{ RGW Dolomite Well \#11 } \\
\hline $6 / 18 / 2019$ & 506 & 200 \\
\hline \multicolumn{3}{|c|}{ RGW Dolomite Well \#12 } \\
\hline $6 / 18 / 2019$ & 440 & 200 \\
\hline \multicolumn{3}{|c|}{ Site A Borehole \#56 } \\
\hline $6 / 19 / 2019$ & 963 & 200 \\
\hline
\end{tabular}


Table A.2 Gamma Results for Water Samples Collected by Argonne and analyzed by IEMA Results are in picocuries per liter ( $\mathrm{pCi} / \mathrm{L}$ )

\begin{tabular}{|c|c|c|}
\hline \multirow{2}{*}{$\begin{array}{l}\text { Location } \\
\text { Date }\end{array}$} & \multicolumn{2}{|c|}{ Cs-137 } \\
\hline & Result & MDC \\
\hline \multicolumn{3}{|c|}{ Red Gate Woods Well \#5160 } \\
\hline $6 / 18 / 2019$ & $<\mathrm{MDC}$ & 3.8 \\
\hline \multicolumn{3}{|c|}{ RGW Dolomite Well \#11 } \\
\hline $6 / 18 / 2019$ & $<\mathrm{MDC}$ & 3.8 \\
\hline \multicolumn{3}{|c|}{ RGW Dolomite Well \#12 } \\
\hline $6 / 18 / 2019$ & $<M D C$ & 3.8 \\
\hline \multicolumn{3}{|c|}{ Site A Borehole \#56 } \\
\hline $6 / 19 / 2019$ & $\angle \mathrm{MDC}$ & 3.8 \\
\hline \multicolumn{3}{|c|}{ Plot M Borehole \#10 } \\
\hline $3 / 27 / 2019$ & $<M D C$ & 3.8 \\
\hline $6 / 19 / 2019$ & $\angle \mathrm{MDC}$ & 3.8 \\
\hline $9 / 18 / 2019$ & $<\mathrm{MDC}$ & 3.8 \\
\hline $12 / 12 / 2019$ & $<M D C$ & 3.8 \\
\hline \multicolumn{3}{|c|}{ Plot M Borehole \#4 } \\
\hline $3 / 27 / 2019$ & $<\mathrm{MDC}$ & 3.8 \\
\hline $6 / 19 / 2019$ & $\angle \mathrm{MDC}$ & 3.8 \\
\hline $9 / 18 / 2019$ & $<\mathrm{MDC}$ & 3.8 \\
\hline $12 / 12 / 2019$ & $<\mathrm{MDC}$ & 3.8 \\
\hline
\end{tabular}


Table A.3 Total Strontium Results for Water Samples Collected by Argonne and analyzed by IEMA Results are in picocuries per liter (pCi/L)

\begin{tabular}{|c|c|c|}
\hline \multirow{2}{*}{$\begin{array}{l}\text { Location } \\
\text { Date }\end{array}$} & \multicolumn{2}{|c|}{ Strontium } \\
\hline & Result & MDC \\
\hline \multicolumn{3}{|c|}{ Plot M Borehole \#10 } \\
\hline $3 / 27 / 2019$ & $\leq \mathrm{MDC}$ & 1.1 \\
\hline $6 / 19 / 2019$ & $<\mathrm{MDC}$ & 1.1 \\
\hline $9 / 18 / 2019$ & $<\mathrm{MDC}$ & 1.1 \\
\hline $12 / 12 / 2019$ & $\leq \mathrm{MDC}$ & 1.1 \\
\hline \multicolumn{3}{|c|}{ Plot M Borehole \#4 } \\
\hline $3 / 27 / 2019$ & $<\mathrm{MDC}$ & 1.1 \\
\hline $6 / 19 / 2019$ & $<\mathrm{MDC}$ & 1.1 \\
\hline $9 / 18 / 2019$ & $<\mathrm{MDC}$ & 1.1 \\
\hline $12 / 12 / 2019$ & $\leq \mathrm{MDC}$ & 1.1 \\
\hline \multicolumn{3}{|c|}{ Site A Borehole \#56 } \\
\hline $6 / 19 / 2019$ & 1.8 & 1.1 \\
\hline \multicolumn{3}{|c|}{ RGW Dolomite Well \#11 } \\
\hline $6 / 18 / 2019$ & $<\mathrm{MDC}$ & 1.1 \\
\hline \multicolumn{3}{|c|}{ RGW Dolomite Well \#12 } \\
\hline $6 / 18 / 2019$ & $<\mathrm{MDC}$ & 1.1 \\
\hline \multicolumn{3}{|c|}{ Red Gate Woods Well \#5160 } \\
\hline $6 / 18 / 2019$ & $\leq \mathrm{MDC}$ & 1.1 \\
\hline
\end{tabular}





\section{Argonne}

Environment, Safety, Health, and Quality Directorate

Argonne National Laboratory

9700 South Cass Avenue, Bldg. 200

Argonne, IL 60439

www.anl.gov 